\title{
Neuroendocrine integration of nutritional signals on reproduction
}

\author{
Maggie C Evans and Greg M Anderson \\ Centre for Neuroendocrinology and Department of Anatomy, University of Otago School of \\ Medical Sciences, Dunedin, New Zealand
}

Correspondence should be addressed to M C Evans

Email

maggie.evans@anatomy.

otago.ac.nz

\begin{abstract}
Reproductive function in mammals is energetically costly and therefore tightly regulated by nutritional status. To enable this integration of metabolic and reproductive function, information regarding peripheral nutritional status must be relayed centrally to the gonadotropin-releasing hormone (GNRH) neurons that drive reproductive function. The metabolically relevant hormones leptin, insulin and ghrelin have been identified as key mediators of this 'metabolic control of fertility'. However, the neural circuitry through which they act to exert their control over GNRH drive remains incompletely understood. With the advent of Cre-LoxP technology, it has become possible to perform targeted gene-deletion and gene-rescue experiments and thus test the functional requirement and sufficiency, respectively, of discrete hormone-neuron signaling pathways in the metabolic control of reproductive function. This review discusses the findings from these investigations, and attempts to put them in context with what is known from clinical situations and wild-type animal models. What emerges from this discussion is clear evidence that the integration of nutritional signals on reproduction is complex and highly redundant, and therefore, surprisingly difficult to perturb. Consequently, the deletion of individual hormone-neuron signaling pathways often fails to cause reproductive phenotypes, despite strong evidence that the targeted pathway plays a role under normal physiological conditions. Although transgenic studies rarely reveal a critical role for discrete signaling pathways, they nevertheless prove to be a good strategy for identifying whether a targeted pathway is absolutely required, critically involved, sufficient or dispensable in the metabolic control of fertility.
\end{abstract}
Key Words
- insulin
- leptin
- ghrelin
- GNRH
- fertility

\section{Introduction}

Mammals, particularly females, must invest an enormous amount of energy into conceiving, carrying and rearing their progeny to preserve their genetic lineage. Therefore, to ensure adequate energy is available to support the high demands of pregnancy and successful weaning of offspring, reproductive function tends to become suppressed during times of low-energy availability. For this coordinated regulation of energy homeostasis and fertility to occur, the hypothalamic-pituitary-gonadal (HPG) axis governing reproductive function must
(C) 2017 Society for Endocrinology Printed in Great Britain receive and integrate information about peripheral metabolic status. Indeed, each level of the HPG axis has the capacity to respond to changing levels of nutritional cues (Comninos et al. 2014). However, the gonadotropinreleasing hormone (GNRH) neurons residing in the hypothalamus are the primary drivers of reproductive function, and impaired GNRH signaling is considered the underlying cause of reproductive suppression due to nutritional stress.

Published by Bioscientifica Ltd. 
Under normal conditions, GNRH is secreted in a pulsatile manner into the hypophyseal portal circulation and travels to the anterior pituitary gland where it stimulates the release of the gonadotropins (luteinizing hormone (LH) and follicle-stimulating hormone (FSH)) which then go on to drive gonadal function (Christian \& Moenter 2010, Herbison 2016). However, during periods of energetic stress, GNRH pulses become suppressed, which in turn reduces pituitary secretion of the gonadotropins, ultimately resulting in hypothalamic hypogonadism (Compagnucci et al. 2002, Castellano et al . 2005, Huang et al. 2008). Although human obesity is unquestionably associated with infertility (Souter et al. 2011), suppression of neuroendocrine reproductive function due to nutritional stress can occur independently from long-term changes in adiposity and is largely due to immediate changes in energy availability (Cameron \& Nosbisch 1991, Loucks et al. 1998, Wade \& Jones 2004). Furthermore, the suppression of GNRH/LH pulsatility is related to the severity of the energetic stress (De Souza et al. 2007); yet, the dependence of LH pulsatility on energy availability appears to be nonlinear (Loucks \& Thuma 2003). Although this delicate control of metabolic and reproductive function is known to occur primarily in the hypothalamus, unraveling the specific neural substrates and nutritional signals involved remains an active and challenging area of research. Not only are there numerous nutritional signals relaying information about peripheral energy status centrally but also the hypothalamic (and extra-hypothalamic) circuitry able to receive information from these signals and then go on to modulate HPG axis function is extensive.

In response to an energetic stress, such as an acute fast or chronic under-nutrition, a series of events involving a multitude of gut- and adipose-derived hormone responses (as well as activation of the stress axes and counter-regulatory response) is initiated, and it seems likely the consequent suppression of the reproductive neuroendocrine axis is due to the net effect of all of these. Trying to disentangle the specific pathways by which each factor independently exerts its impact on GNRH release proves extremely difficult and is arguably not an experimentally and physiologically meaningful approach, except perhaps in cases of specific genetic deficiencies, as no single pathway is ever operating in isolation in vivo. Nevertheless, identifying the discrete mechanisms underlying nutritional infertility provides important insight into how peripheral metabolic status is relayed centrally to the GNRH neurons and also highlights the complexity and inherent redundancies built in to safeguard reproductive function and thus species' survival.
This review will attempt to highlight some of the key neuroendocrine pathways whereby nutritional signals modulate reproduction, while also emphasizing the inherent redundancies of the system through discussions of whether identified pathways are absolutely required for, critically involved in and/or sufficient to permit the normal metabolic control of fertility.

\section{Identifying the key players}

As mentioned previously, the body's response to nutritional stress is multifaceted, so identifying the specific components critically involved in the suppression of reproductive function is challenging. Clinically, women presenting with nutritional infertility (i.e. functional hypothalamic amenorrhea (FHA)) exhibit a range of endocrine-metabolic aberrations, including (but not limited to) altered levels of gut and adipose hormones, reduced levels of plasma glucose, suppressed thyroid function, altered growth hormone secretion patterns and chronically elevated cortisol concentrations (Berga et al. 1989, Laughlin \& Yen 1997, Laughlin et al. 1998, Schneider \& Warren 2006, Scheid \& De Souza 2010, Corr et al. 2011). Although it remains a possibility that each of these factors independently suppresses the neuroendocrine reproductive axis, we know from both animal and clinical studies that certain nutritional signals, such as leptin, insulin and ghrelin, exert a more critical influence over GNRH/LH pulsatility (and thus fertility) than others and that in at least some cases their effects are additive. This review will therefore focus on the discrete mechanisms whereby these key nutritional factors influence HPG function and will also briefly touch upon the role of stress axes activation in reproductive suppression due to low energy availability.

\section{Leptin}

Leptin, the hormone product of the obesity gene $(\mathrm{Ob})$, appears to be a particularly important factor. Leptin is secreted from adipocytes into the bloodstream in proportion to body fatness, and signals energy sufficiency and acts on the hypothalamus to suppress feeding and increase energy expenditure. Serum leptin concentrations change gradually over time in response to changes in fat mass, but fall rapidly in response to complete fasting (Boden et al. 1996, Chan et al. 2003), and this fall in leptin concentration is thought to mediate reproductive suppression due to nutritional stress. For example, preventing the

Published by Bioscientifica Ltd. 
starvation-induced fall in leptin with exogenous leptin was shown to prevent the starvation-induced delay in ovulation in female mice (Ahima et al. 1996). Accordingly, women with infertility due to a negative energy balance exhibit reduced circulating leptin concentrations (Laughlin \& Yen 1997, Corr et al. 2011), and administration of recombinant human leptin to these women not only increased their $\mathrm{LH}$ pulsatility and restored ovulation but also improved their thyroid and growth hormone axes, independent from dietary changes or weight gain (Welt et al. 2004). These data suggest that an acute decrease in circulating leptin plays a key role in mediating the effects of low energy availability on reproductive function.

In further support of leptin's role in the metabolic regulation of fertility, humans and mice with a congenital leptin deficiency $(o b / o b)$, as well as leptin receptor (LepR)deficient $(d b / d b)$ mice, are infertile and obese despite being energy replete, and leptin treatment is sufficient to restore body weight control and reproductive function in leptindeficient individuals (Ingalls et al. 1950, Hummel et al. 1966, Barash et al. 1996, Chehab et al. 1997, Mounzih et al. 1997, Farooqi et al. 1999, 2002). Like the global LepRdeficient mice, mice exhibiting forebrain neuron-specific deletion of LepR are also infertile and obese, highlighting that leptin's central actions, vs peripheral actions, are critically involved in regulating body weight homeostasis and fertility (Quennell et al. 2009). Lastly, central leptin immune neutralization using leptin antiserum caused a reduction in LH pulsatility in rats (Carro et al. 1997). These findings, among others, convincingly demonstrate that leptin plays an important physiological role in the regulation of metabolic and reproductive function.

\section{Insulin}

The pancreatic peptide hormone insulin (best known for regulating glucose homeostasis and body weight regulation (Belgardt \& Bruning 2010)) has also emerged as a key modulator of reproductive function. Clinically, diabetic insulin insufficiency (i.e. type 1 diabetes) in humans is associated with delayed puberty, reduced LH pulsatility and hypothalamic hypogonadism, despite sufficient energy availability; yet, improved insulin therapy has ameliorated many of these issues (Codner et al. 2012). Additionally, reduced insulin levels, presumably due to energy deficiency, are likewise associated with suppression of neuroendocrine reproductive function in women with FHA (Laughlin \& Yen 1997), which further suggests insulin promotes GNRH/LH secretion. Conversely, hyperinsulinemia and/or insulin resistance (i.e. type 2 diabetes), are often associated with elevated LH pulsatility and polycystic ovary syndrome (PCOS) (Laughlin et al. 1997), and insulinsensitizing drugs (e.g. metformin) have successfully been used to induce ovulation and treat some of the pathophysiological features associated with PCOS (Katsiki \& Hatzitolios 2010). Encouragingly, animal studies support these clinical findings. For example, lean and normoglycemic female mice exhibiting varying degrees of insulin resistance and hyperinsulinemia were shown to have subtle alterations in their HPG axis and also had polyovular follicles (Nandi et al. 2010). Although insulin can act both peripherally and centrally to modulate HPG axis function, we know that insulin's central actions play a role in mediating many of its reproductive effects as mice exhibiting brain-specific deletion of insulin receptors (InsR) exhibit subfertility due to mild hypothalamic hypogonadism (Bruning et al. 2000). However, in contrast to these brain-specific InsR-knockout mice, our group recently demonstrated that mice exhibiting forebrain neuron-specific deletion of InsR displayed normal HPG axis function (Evans et al. 2015), which challenges the hypothesis that neuronal insulin signaling is required. Nevertheless, many findings implicate abnormal insulin signaling in the pathogenesis of reproductive dysfunction. However, in contrast to leptin, central insulin signaling is not absolutely required for fertility.

\section{Ghrelin}

Unlike the anorexigenic peptides insulin and leptin, which promote GNRH/LH pulsatility and reproductive function, the orexigenic peptide ghrelin has been shown to consistently suppress GNRH pulsatility and gonadotropin release (Furuta et al. 2001, Kluge et al. 2007, 2009, 2012, 2013, Kluge 2012). Although ghrelin is predominantly produced in the stomach, ghrelinexpressing neurons have also been identified in the hypothalamus (Cowley et al. 2003), yet it remains unclear whether the actions of brain-derived ghrelin are the same as those for circulating ghrelin. Under normal conditions, circulating ghrelin exhibits a circadian pattern whereby its concentration becomes elevated in anticipation of meals. However, in women exhibiting chronic undernutrition, chronically elevated basal ghrelin levels are observed and are correlated with suppressed reproductive function (Scheid \& De Souza 2010). Ghrelin deficiency, on the other hand, does not significantly affect fertility or feeding behavior in mice (Sun et al. 2003). The latter observation is likely due to the fact that the ghrelin receptor (the growth hormone secretagogue receptor

Published by Bioscientifica Ltd. 
type 1a (GHSR1a)) has constitutive activity (Holst et al. 2003, Holst \& Schwartz 2004), so even in the absence of ghrelin peptide, ghrelin signaling is not abolished. Considering ghrelin's inhibitory actions on GNRH release, the lack of fertility phenotype observed in the ghrelinknockout mice is perhaps not surprising. It would arguably have been more informative to determine whether the ghrelin-knockout mice were protected against a fastinginduced reduction in LH secretion.

Chronic overexpression of ghrelin, on the other hand, caused an acute increase in food intake and body weight in mice, but failed to cause long-term impacts (Qi et al. 2015), likely due to compensation by other factors. Unfortunately, reproductive parameters were not assessed in these mice. Nevertheless, under normal physiological conditions, the increase in circulating ghrelin concentrations that accompanies nutritional stress is thought to antagonize leptin's and insulin's effects, thereby acting as a 'brake' on fertility. In support of this, inhibition of ghrelin signaling improves the reproductive phenotype of leptindeficient mice (Zhu et al. 2013). Furthermore, exercising women with amenorrhea exhibit plasma ghrelin levels that are approximately $85 \%$ greater than those observed in their normally cycling peers (De Souza et al. 2004), and women with disordered eating and amenorrhea also exhibit chronically elevated ghrelin levels (Schneider \& Warren 2006, Schneider et al. 2008), which may be due to reduced leptin-induced inhibition of ghrelin (Kalra et al. 2005). These studies strongly implicate ghrelin as a key player in the mechanism whereby low energy availability suppresses the neuroendocrine reproductive axis.

\section{Other nutritional signals}

Although leptin, insulin and ghrelin appear to be the major signals whereby peripheral metabolic status is relayed to the neuroendocrine reproductive axis, there are many other nutritional factors that also influence HPG axis function, as thoroughly reviewed by Comninos and coworkers (Comninos et al. 2014). For example, the anorectic gut peptides glucagon-like peptide (GLP)-1 and peptide YY3-36 (PYY) are both stimulated by food intake and appear to facilitate GNRH release and HPG function (Beak et al. 1998, MacLusky et al. 2000, Pinilla et al. 2006). Adiponectin, a protein hormone secreted by white adipocytes, is also implicated in the metabolic control of fertility and has been shown to have a predominantly inhibitory effect on the HPG axis (Klenke et al. 2014). However, the roles of these metabolic hormones in conveying nutritional status centrally do not appear to be as influential as those of leptin, insulin and ghrelin.

\section{The GNRH neuronal network}

Although GNRH neurons serve as the final gatekeepers of the neuroendocrine reproductive axis, they are in turn regulated by a network of hormone-sensitive afferent neurons (termed the GNRH neuronal network) and it is primarily through this specialized network that the influence of leptin, insulin and ghrelin, as well as other peripheral signals of nutritional status (Comninos et al. 2014), appears to converge on the neuroendocrine reproductive axis.

Indeed, GNRH neurons themselves can directly detect some nutritional signals, including insulin and ghrelin (Farkas et al. 2013, Evans et al. 2014a, DiVall et al. 2015), as well as glucose (Zhang et al. 2007), PYY (Pinilla et al. 2007) and adiponectin (Klenke et al. 2014). Although it might be speculated that disruption of metabolic regulation at the level of the final common output of the GNRH neuronal network would have more profound effects than at the level of individual afferent neurons, in most cases, direct hormone-GNRH communication does not play a critical role when it comes to the regulation of fertility by nutritional factors. For example, although mice exhibiting brain-specific deletion of InsR (Bruning et al. 2000) or forebrain neuron-specific deletion of LepR (Quennell et al. 2009) were subfertile and infertile, respectively, GNRH-specific deletion of InsR (GNRHIRKO mice) (Divall et al. 2010) or LepR (Quennell et al. 2009) did not result in any reproductive perturbations. Interestingly, however, GNRH-IRKO mice were protected from high-fat diet-induced infertility (DiVall et al. 2015), suggesting direct insulin-GNRH signaling may play a role in obesity-related infertility. With regard to ghrelin, although it can modulate GNRH neurons directly, at least in brain slice preparations (Farkas et al. 2013), many of its neuroendocrine effects appear to be mediated through hypothalamic circuitry afferent to GNRH neurons (Forbes et al. 2009, Schaeffer et al. 2013). It thus appears the neuroendocrine integration of nutritional signals on reproduction largely occurs upstream of GNRH neurons.

Although this indirect mechanism of action may seem redundant and inefficient, it probably allows the metabolic control of fertility to be more fine-tuned and fail-safe. Instead of GNRH neurons acting as the receivers, processers and integrators of individual nutritional signals, it appears information regarding peripheral energy status http://jme.endocrinology-journals.org DOI: 10.1530/JME-16-0212
() 2017 Society for Endocrinology Printed in Great Britain
Published by Bioscientifica Ltd 
is first channeled through upstream circuitry. Information encoded by individual nutritional signals thus becomes contextualized among the information encoded by the others, yielding a comprehensive snapshot of peripheral energy status. The GNRH neurons then receive this integrated information and can respond accordingly, thereby maintaining their role as the final gatekeepers of reproductive function.

Characterizing the neuropeptide and/or neurotransmitter identities of this 'fuel-gauging' network subserving GNRH neurons, as well as their role in mediating the metabolic control of fertility, remains an active area of research. Although many questions remain unanswered, a lot of headway has been made (Table 1). Perhaps not surprisingly, many of the same neuronal populations previously identified to play a role in energy balance homeostasis have now been identified to play a role in modulating reproductive function as well. Conversely, many neuronal populations previously known to modulate GNRH release are now recognized as integrators of nutritional information.

\section{GABA-expressing neurons}

While emphasis is often placed on the role of neuropeptideexpressing populations with regard to the integration of metabolic and reproductive status, the contribution of neurotransmitters also deserves attention. It has been known since the 1980s that gamma-amino butyric acid (GABA) (the main inhibitory neurotransmitter in the mammalian central nervous system) is involved in the regulation of GNRH release both before and after puberty (Adler \& Crowley 1986, Nikolarakis et al. 1988, Donoso et al. 1994, Mitsushima et al. 1994), and that GABAergic afferents compose a major group of synaptic inputs to GNRH neurons. Similarly, it has been known for some time that GABAergic neurons are modulated by nutritional factors, including leptin (Ovesjo et al. 2001). However, it was not until Sullivan and coworkers demonstrated that GABAergic neurons play a role in conveying metabolic information to GNRH neurons (Sullivan et al. 2003, Sullivan \& Moenter 2004) that the role of GABAergic neurons in the integration of nutritional and reproductive status became appreciated. Indeed, the GNRH neurons express both $\mathrm{GABA}_{\mathrm{A}}$ and $G_{A B A}$ receptor isoforms. Binding of GABA to the $G_{A B A}$ receptor causes an inhibition of pulsatile GNRH release, but the effect of $\mathrm{GABA}_{\mathrm{A}}$ receptor activation can be either excitatory or inhibitory depending on the chloride concentration within the GNRH neuron (Herbison \& Moenter 2011).

To investigate the role(s) of leptin and insulin signaling via GABAergic neurons in the control of HPG axis function, our lab generated mice exhibiting GABA-specific deletion of LepR (Zuure et al. 2013) and InsR (Evans et al. 2014b) and demonstrated that leptin signaling, but not insulin signaling, via GABAergic neurons is a major component of the circuitry whereby peripheral metabolic status is relayed to the neuroendocrine reproductive and metabolic axes. Mice lacking LepR from GABA neurons were profoundly obese and exhibited delayed puberty and subfertility (Zuure et al. 2013), whereas mice lacking InsR from GABA neurons exhibited a very mild metabolic phenotype and normal pubertal development and fertility (Evans et al. 2014b). Although it remains a possibility that the reproductive impairments observed in the GABA-specific LepR-knockout mice were directly related to their obesity phenotype, our lab and others have demonstrated that reproductive competency can be maintained despite profound obesity (Bates et al. 2003, Singireddy et al. 2013), suggesting leptin-GABA signaling is directly involved in the control of HPG axis function. In contrast, insulin-GABA signaling does not appear to be critically involved in regulating fertility.

Although leptin signaling via GABAergic neurons appears to play a critical role in the regulation of fertility, many GABAergic neurons co-express other transmitters (Table 2), including NPY and AgRP (Meister 2007), kisspeptin (Cheong et al. 2015) and dopamine (Olson \& Nestler 2007, Marshall et al. 2016), for example, and it is therefore possible that both the neuropeptide(s) and/or neurotransmitter(s) released from these neurons act as the effectors on GNRH neurons. At this stage, it is not clear whether leptin signaling via GABAergic neurons critically regulates fertility by modulating GABA release or the release of other transmitters, or both. However, evidence for the latter is strong. Furthermore, although insulin signaling via GABAergic neurons themselves does not appear to play a critical role (Evans et al. $2014 b$ ), insulin was shown to increase the number of synaptic $\mathrm{GABA}_{\mathrm{A}}$ receptors to postsynaptic domains, which is the limiting factor in eliciting a greater synaptic response (Wan et al. 1997, Bell-Horner et al. 2006). Therefore, insulin actions on GABAergic efferent neurons, via modulation of the GABA postsynaptic response, may explain some of insulin's central effects on GNRH release.
() 2017 Society for Endocrinology Printed in Great Britain
Published by Bioscientifica Ltd 
Table 1 Gene deletion studies: summary of the metabolic control of fertility.

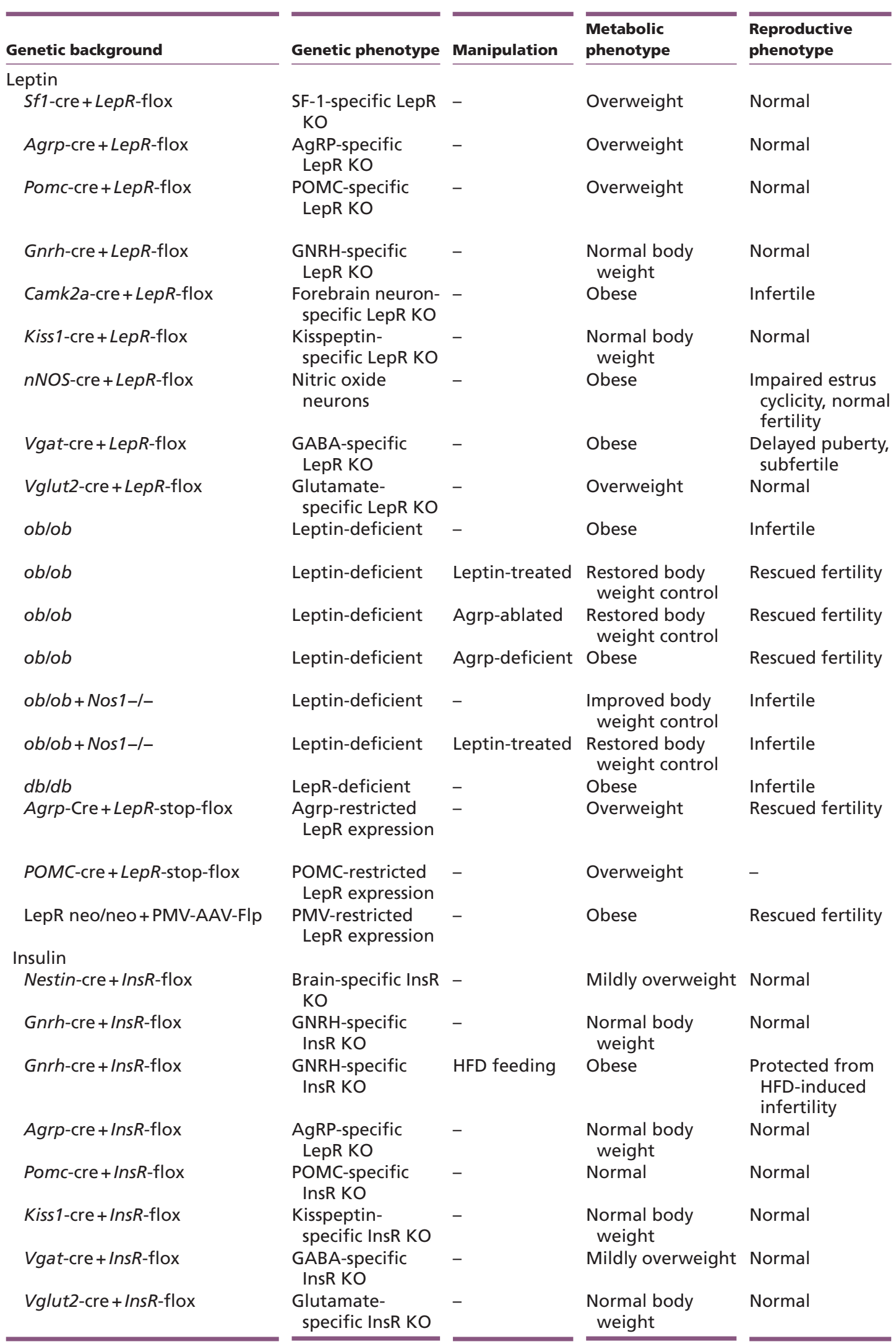

References

Bingham et al. (2008)

van de Wall et al. (2008)

van de Wall et al. (2008), shi et al.

(2010)

Quennell et al.

(2009)

Quennell et al.

(2009)

Donato et al. (2011)

Leshan et al. (2012)

Zuure et al. (2013)

Zuure et al. (2013)

Ingalls et al. (1950),

Zhang et al. (1994)

Mounzih et al. (1997)

Wu et al. (2012)

Sheffer-Babila et al. (2013)

Bellefontaine et al. (2014)

Bellefontaine et al. (2014)

Hummel et al. (1966)

O Egan \& GM

Anderson (unpub-

lished observations)

Huo et al. (2009)

Donato et al. (2011)

Bruning et al. (2000)

Divall et al. (2010)

DiVall et al. (2015)

Konner et al. (2007)

Konner et al. (2007)

Evans et al. (2014a)

Evans et al. (2014b)

Evans et al. (2014b) 
Table 1 Continued.

\begin{tabular}{|c|c|c|c|c|c|}
\hline Genetic background & Genetic phenotype & Manipulation & $\begin{array}{l}\text { Metabolic } \\
\text { phenotype }\end{array}$ & $\begin{array}{l}\text { Reproductive } \\
\text { phenotype }\end{array}$ & References \\
\hline Camk2a-cre +InsR-flox & $\begin{array}{l}\text { Forebrain } \\
\text { neuron-specific } \\
\text { InsR KO }\end{array}$ & - & Mildly overweight & Normal & Evans et al. (2015) \\
\hline Pomc-cre + InsR-flox + LepR-flox & $\begin{array}{l}\text { POMC-specific } \\
\text { LepR and InsR } \\
\text { KO }\end{array}$ & - & Overweight & Subfertile & Hill et al. (2010) \\
\hline$K i s s 1$-cre + InsR-flox + LepR-flox & $\begin{array}{l}\text { Kisspeptin- } \\
\text { specific LepR } \\
\text { and InsR KO }\end{array}$ & - & $\begin{array}{l}\text { Normal body } \\
\text { weight }\end{array}$ & $\begin{array}{l}\text { Altered pubertal } \\
\text { timing }\end{array}$ & Qiu et al. (2015) \\
\hline \multicolumn{6}{|l|}{ Other } \\
\hline Ghrelin-/- & Ghrelin-deficient & - & $\begin{array}{l}\text { Normal body } \\
\text { weight }\end{array}$ & Normal & Sun et al. (2003) \\
\hline Ghsr-I- & $\begin{array}{l}\text { Ghrelin receptor- } \\
\text { deficient }\end{array}$ & - & Underweight & - & Sun et al. (2008) \\
\hline Nestin-Cre + Sf1 flox/- & $\begin{array}{l}\text { Brain-specific SF1 } \\
\text { KO }\end{array}$ & - & $\begin{array}{l}\text { Normal body } \\
\text { weight }\end{array}$ & $\begin{array}{l}\text { Impaired estrus } \\
\text { cyclicity, } \\
\text { subfertile }\end{array}$ & Kim et al. (2010) \\
\hline
\end{tabular}

\section{Glutamate-expressing neurons}

Glutamate is the primary excitatory neurotransmitter used by the majority of neurons in the CNS, and a body of evidence demonstrates glutamate regulates GNRH neurons' excitability and thus secretion. As reviewed by Iremonger and coworkers (Iremonger et al. 2010), many studies have shown that glutamate agonists and antagonists injected into the brain can stimulate or inhibit LH secretion, respectively (Lopez et al. 1990, Brann \& Mahesh 1995, Ping et al. 1997). Glutamate likely exerts its influence via direct effects on GNRH neurons, as TenaSempere's lab demonstrated that glutamate-stimulated
LH secretion occurs in a kisspeptin-independent manner (Garcia-Galiano et al. 2012). Furthermore, neurons in the ventral premamillary nucleus (PMV) of the hypothalamus, which mediate some of leptin's metabolic influences on GNRH function (Donato et al. 2011), are almost exclusively glutamatergic (Kocsis et al. 2003), supporting a role for glutamate-expressing neurons in the metabolic control of fertility.

To investigate the direct effects of leptin and insulin signaling via glutamatergic neurons in the metabolic regulation of fertility, our lab generated glutamatespecific LepR KO and InsR KO mice. In contrast to the

Table 2 Neuropeptide and transmitter co-expression.

\begin{tabular}{|c|c|c|c|}
\hline $\begin{array}{l}\text { Primary neuropeptide/ } \\
\text { transmitter population }\end{array}$ & Sub-population & Co-expression & Estimated co-expression (\%) \\
\hline AgRP/NPY & ARC & GABA & $\leq 100$ \\
\hline \multirow[t]{2}{*}{ POMC/CART } & ARC & GABA & $<40$ \\
\hline & ARC & Glutamate & $<60$ \\
\hline \multirow[t]{5}{*}{ Kisspeptin } & AVPV & Glutamate & $<25$ \\
\hline & AVPV & Dopamine & $\leq 50$ \\
\hline & ARC & GABA & $<25$ \\
\hline & ARC & Glutamate & $<75$ \\
\hline & ARC & GABA & $<15$ \\
\hline nNOS & ARC & GABA & $<50$ \\
\hline \multirow[t]{2}{*}{ SF1 } & $\mathrm{VMH}$ & Glutamate & $\leq 75$ \\
\hline & VMH & GABA & $\leq 20$ \\
\hline \multirow[t]{4}{*}{ Dopamine } & ARC & GABA & $\leq 80$ \\
\hline & VTA & GABA & $\leq 40$ \\
\hline & VTA & Glutamate & $\leq 20$ \\
\hline & AVPV & Kisspeptin & $\leq 50$ \\
\hline
\end{tabular}

References

Marshall et al. (2016)

Wittmann et al. (2013)

Wittmann et al. (2013)

Cheong et al. (2015)

Skrapits et al. (2015)

Cheong et al. (2015)

Cheong et al. (2015)

Marshall et al. (2016)

Marshall et al. (2016)

Tong et al. $(2007 a, b)$

Tong et al. $(2007 a, b)$

Marshall et al. (2016)

Merrill et al. (2015)

Kawano et al. (2006)

Skrapits et al. (2015)

AgRP, agouti-related peptide; ARC, arcuate nucleus; AVPV, antero-ventral peri-ventricular nucleus; CART, cocaine-amphetamine-related-transcript; nNOS, neuronal nitric oxide synthase; NPY, neuropeptide Y; POMC, pro-opiomelanocortin; SF1, steroidogenic factor 1; VMH, ventro-medial hypothalamus; VTA, ventral tegmental area.

$\begin{array}{lr}\text { http://jme.endocrinology-journals.org } & \text { ○ } 2017 \text { Society for Endocrinology } \\ \text { DOI: } 10.1530 / J M E-16-0212 & \text { Printed in Great Britain }\end{array}$
Published by Bioscientifica Ltd 
GABA-specific LepR KO mice, which exhibited delayed puberty and reduced fecundity, the glutamate-specific LepR KO mice exhibited normal puberty onset and fertility (Zuure et al. 2013). Glutamate-specific InsR KO mice also exhibited normal HPG axis function (Evans et al. 2014b). Although these studies suggest glutamate is not a critical mediator of the metabolic control of fertility, some evidence suggests otherwise. For example, LepR-null mice exhibiting PMV-restricted re-expression of endogenous LepR showed rescued puberty onset and improved fertility (Donato et al. 2011). As mentioned previously, the PMV is almost exclusively glutamatergic, and these data suggest the PMV is a key site for leptin's permissive action at the onset of puberty. Although speculative, it appears leptin signaling in glutamate neurons may be sufficient to permit puberty onset and reproductive function, but unlike leptin signaling in GABA neurons, it is not critically involved.

\section{NPY/AgRP-expressing neurons}

A subset of GABAergic neurons in the arcuate nucleus (ARC) of the hypothalamus co-express neuropeptide $\mathrm{Y}$ (NPY) and agouti-related peptide (AgRP), which are both orexigenic neuropeptides shown to have predominantly inhibitory effects on GNRH neurons (McShane et al. 1992, Cone 2005, Vulliemoz et al. 2005, Roa \& Herbison 2012). NPY/AgRP neurons, in turn, are directly modulated by insulin (Konner et al. 2007) and leptin (Elias et al. 1999) and are also innervated by ghrelin-expressing neurons (Cowley et al. 2003). Insulin and leptin inhibit NPY/ AgRP-expressing neurons (Sato et al. 2005, Konner et al. 2007), thereby reducing the inhibitory tone of NPY/ AgRP on GNRH neurons. It should be noted that the inhibitory effects of AgRP on GNRH neurons are likely mediated, at least in part, via AgRP's antagonism of stimulatory melanocortin receptor (MC4) signaling (Ollmann et al. 1997, Cowley et al. 1999). In contrast to leptin and insulin, ghrelin stimulates NPY/AgRP neurons, thereby promoting NPY/AgRP-induced suppression of GNRH release (Lebrethon et al. 2007). NPY/AgRP neurons are thus aptly equipped to integrate metabolic and reproductive function.

Physiologically, fasting causes an increase in Agrp (Korner et al. 2001) and Npy (Brady et al. 1990) mRNA expression and concomitant suppression of GNRH drive (Kalamatianos et al. 2008). Interestingly, although NPYknockout mice did not exhibit a fertility phenotype under normal conditions, they were protected against the fasting-induced suppression of LH release that was observed in wild-type control mice (Hill \& Levine 2003), suggesting NPY plays a critical role in the mechanism whereby HPG function becomes suppressed in response to low energy availability. The decreased leptin and insulin concentrations observed in response to fasting are thought to mediate this effect, as treatment with insulin or leptin decreased Npy mRNA and peptide expression in fasted animals (Schwartz et al. 1991, Wang \& Leibowitz 1997, Korner et al. 2001). Fasting is also accompanied by an increase in circulating ghrelin concentration, which may further promote the increased NPY expression observed in response to a fast (Asakawa et al. 2001). However, as mentioned previously, ghrelin receptors have constitutive activity (Holst et al. 2003, Holst \& Schwartz 2004), so even in the absence of fasting, the ghrelin receptor promotes tonic NPY/AgRP neuronal activation. Accordingly, insulin-deficient diabetic rats show increased hypothalamic expression of Npy mRNA and peptide, despite being energy replete, and insulin administration restored NPY levels (Abe et al. 1991). This suggests insulin is critically involved in restraining tonic NPY/AgRP activity.

Further supporting the idea that insulin and/or leptin must restrain NPY/AgRP neurons to permit fertility, it was shown that ablating NPY/AgRP-expressing neurons in leptin-deficient $(o b / o b)$ diabetic mice was able to restore their fertility, food intake regulation and glucose tolerance (Wu et al. 2012). Additionally, AgRP deficiency alone (vs neuronal ablation) in LepR-null $(d b / d b)$ mice was also able to rescue their HPG axis function (ShefferBabila et al. 2013). Lastly, our lab recently showed that fertility can be completely reinstated in otherwise LepRdeficient mice by restoring leptin sensitivity exclusively in NPY/AgRP neurons (O Egan \& GM Anderson, unpublished observations), demonstrating that leptinNPY/AgRP signaling alone can sufficiently block NPY/ AgRP-induced inhibition of reproductive function. As both NPY-knockout mice and AgRP-deficient mice were shown to exhibit improved reproductive phenotypes in response to nutritional stress (fasting and LepR deficiency, respectively), it appears that they are both independently involved in the suppression of GNRH. These data highlight both the powerful inhibitory tone NPY/AgRP-expressing neurons exert on reproductive function and also reveal that leptin signaling exclusively in NPY/AgRP neurons is sufficient to permit fertility (Vulliemoz et al. 2005).

As mentioned previously, reactivation of LepR exclusively in the PMV was also sufficient to induce puberty onset (Donato et al. 2011). However, unlike the PMV-LepR 'rescue' mice, the NPY/AgRP-LepR 'rescue' mice exhibited

Published by Bioscientifica Ltd 
a slightly attenuated body weight phenotype. Although it thus remains a possibility that the improved reproductive function observed in the NPY/AgRP-LepR 'rescue' mice might be due in part to their improved body weight, this seems unlikely as, in addition to the PMV-LepR 'rescue' experiment, there are several accounts demonstrating that fertility can be maintained in morbidly obese mice (Bates et al. 2003, Singireddy et al. 2013).

\section{POMC/CART-expressing neurons}

Acting in opposition to the NPY/AgRP neurons are ARC neurons encoding pro-opiomelanocortin (POMC, a precursor of the anorexigenic melanocortin peptides) and cocaine-amphetamine-related transcript (CART) (POMC/CART neurons). These neurons play a key role in energy homeostasis by promoting satiety and suppressing feeding (Baskin et al. 1999, Meister 2007); yet, they have also been shown to promote GNRH neuron activity, presumably via direct actions (Leranth et al. 1988, Roa \& Herbison 2012, True et al. 2013). Sub-populations of POMC neurons have been shown to co-express GABA and glutamate (Table 2). Perhaps not surprisingly, POMC/ CART neurons are regulated by insulin, leptin and ghrelin (Havel et al. 2000, Cowley et al. 2001, 2003, Balthasar et al. 2004, Williams et al. 2010). Peripheral ghrelin peptide indirectly inhibits the activity of POMC/CART neurons in mice (Cowley et al. 2003), but POMC/CART neurons may also be directly modulated by ghrelin-expressing neurons via synaptic communication (Guan et al. 2008). Leptin activates POMC neurons to promote satiety, and in the absence of leptin-POMC signaling, an obesity phenotype results (Balthasar et al. 2004). Insulin's appetite-suppressing effects are also largely mediated via POMC neurons (Benoit et al. 2002); yet, in the absence of direct insulin-POMC signaling, mice exhibit normal body weight regulation (Konner et al. 2007), presumably due to the developmental compensation provided by leptin. These data suggest leptin actions on POMC neurons are required for normal energy homeostasis, whereas insulin actions are not.

With regard to fertility, insulin or leptin actions alone on POMC neurons do not appear to play a critical role in conveying energy status to the HPG axis, as mice exhibiting POMC-specific deletion of either LepR (Balthasar et al. 2004) or InsR (Konner et al. 2007) exhibited completely normal fertility. Interestingly, mice exhibiting POMCspecific deletion of both LepR and InsR did present with reduced fertility, but not infertility (Hill et al. 2010). This suggests leptin and insulin exert overlapping control of
POMC neurons, such that in the absence of leptin-POMC signaling, sufficient compensation occurs via insulin, and vice versa. However, despite exhibiting subfertility, the mice lacking both leptin- and insulin-POMC signaling were still able to reproduce, suggesting insulin and leptin can act via other circuitry to permit sufficient activation of the HPG axis, further highlighting how redundancy in the mechanisms whereby nutritional signals reach GNRH neurons confers reproductive resilience.

\section{Kisspeptin-expressing neurons}

The endogenous G-protein-coupled receptor 54 (GPR54) ligand, kisspeptin, has been identified as the most potent secretagogue of GNRH (Irwig et al. 2004) and is likewise implicated in the timing of puberty onset (Han et al. 2005) and the mechanism whereby energy status is relayed to the reproductive axis (Tena-Sempere 2006, Castellano et al. 2010, De Bond et al. 2016). Although kisspeptin gene (Kiss1) expression is primarily regulated by gonadal steroid hormones (Smith 2009), it is also modulated by metabolic status such that its expression becomes reduced in response to metabolic stress, such as fasting (Castellano et al. 2005) or prolonged high-fat diet feeding (Quennell et al. 2011). Approximately 40\% of ARC kisspeptin neurons were shown to express the gene for LepR (Smith et al. 2006) in one report, but subsequent work suggests a more modest level of co-expression (Louis et al. 2011, Cravo et al. 2013) and failed to show direct leptin-kisspeptin signaling (Quennell et al. 2011). InsR protein expression was also observed in a subset of kisspeptin immunoreactive neurons (Evans et al. 2014a). Physiologically, kisspeptin treatment to women with acquired GNRH deficiency due to low energy availability was able to stimulate GNRH/LH release (Jayasena et al. 2009,2010 ), suggesting that neuroendocrine integration of nutritional signals converge upstream of, or directly on, kisspeptin neurons. Accordingly, leptin treatment to $o b / o b$ mice increased Kiss1 mRNA expression (Smith et al. 2006), whereas ghrelin administration was shown to reduce kisspeptin expression and LH pulse frequency in ad libitum fed rats (Forbes et al. 2009). Also, insulindependent diabetic rats exhibit reduced kisspeptin mRNA levels (Castellano et al. 2006). Interestingly, insulin administration did not rescue the reduced kisspeptin gene expression observed in these diabetic rats; yet, leptin administration was sufficient to restore Kiss1 mRNA levels and LH concentration (Castellano et al. 2006).

Although ample evidence suggests leptin and insulin modulate kisspeptin neurons, their direct influences are

Published by Bioscientifica Ltd. 
not required for normal reproductive control, as mice exhibiting kisspeptin-specific deletion of either InsR (Evans et al. 2014a) or LepR (Donato et al. 2011) retain normal HPG axis function. Mice exhibiting kisspeptinspecific deletion of both InsR and LepR were also completely fertile, yet, had delayed pubertal timing (Qiu et al. 2015). However, Manfredi-Lozano and coworkers recently documented a novel leptin-melanocortinkisspeptin-GNRH signaling pathway, and it is thus likely that leptin's effects on kisspeptin are mediated indirectly via POMC neurons (Manfredi-Lozano et al. 2016). Conversely, kisspeptin was shown to directly excite POMC neurons and indirectly inhibit NPY neuronal activity (Fu \& van den Pol 2010), so it appears kisspeptin's role in the mechanism whereby nutritional status is conveyed to GNRH neurons could be both upstream and downstream of POMC neurons. Interestingly, over half of ARC kisspeptin neurons were recently shown to arise from Pomc-expressing progenitors (Sanz et al. 2015). This may explain, at least in part, why prenatal nutritional insults, which are known to impair hypothalamic development of the melanocortin system and thus cause disturbances to adulthood energy homeostasis (Wattez et al. 2013), can cause reproductive impairments (Dupont et al. 2012).

\section{GALP-expressing neurons}

Galanin-like peptide (GALP)-expressing neurons represent another population of neurons that contributes to the metabolic control of fertility (Cunningham 2004, Crown et al. 2007, Shioda et al. 2011). Anatomically, GALP cell bodies are primarily located in the ARC, but their fibers make apparent contacts with GNRH neurons in the rat hypothalamus (Takatsu et al. 2001). GALP-positive nerve terminals were also found to make axo-somatic and axo-dendritic synaptic contacts with GNRH neurons in transgenic rats in which GNRH neurons were tagged with enhanced green fluorescent protein (Takenoya et al. 2006), suggesting GALP can directly regulate GNRH neurons. In turn, GALP neurons express LepR and are regulated by leptin (Jureus et al. 2000, Takatsu et al. 2001, Cunningham et al. 2002) and are also directly modulated by insulin (Fraley et al. 2004). GALP neurons are thus equipped to transduce information regarding nutritional status to the HPG axis.

Physiologically, GALP administration was shown to stimulate LH release in mice (Kauffman et al. 2005), which occurs in a kisspeptin-independent manner (Garcia-Galiano et al. 2012), and GALP infusion was sufficient to rescue the onset of puberty in food-restricted weanling male and female rats (Mohr et al. 2012), demonstrating GALP is modulated by nutritional signals and also facilitates fertility in vivo. Accordingly, rats exhibiting insulin-dependent diabetes have reduced Galp mRNA compared to control animals, and brain insulin administration reversed this effect (Fraley et al. 2004). Galp mRNA levels were also reduced in rats exposed to a 48-h fast, and insulin or leptin administration increased Galp mRNA levels (Jureus et al. 2000, Fraley et al. 2004), suggesting insulin and leptin exhibit overlapping control of GALP expression. Furthermore, subcutaneous insulin and leptin co-administration rescued reproductive function in insulin-dependent diabetic rats; yet, this effect was prevented when a GALP antibody was administered, demonstrating that GALP mediates the ability of leptin and insulin to rescue reproductive function in these rats (Stoyanovitch et al. 2005).

GALP's effects on HPG function may be direct, as GALP was able to directly stimulate GNRH neurons isolated from the rat (Kuramochi et al. 2005) and, as mentioned previously, GALP neurons directly innervate GNRH neurons. However, GALP's effects may also be mediated via kisspeptin neurons, as GALP administration increased Kiss1 mRNA in food-restricted rats (Mohr et al. 2012). However, it does not appear ARC POMC/CART or NPY/ AgRP neurons are involved in mediating GALP's effects on fertility, as GALP was not able to directly modulate their activity (Kuramochi et al. 2005). In contrast, NPY neurons in the dorsomedial nucleus of the hypothalamus were shown to mediate GALP's acute orexigenic feeding actions (Kuramochi et al. 2006), suggesting GALP and NPY neurons may exhibit bi-directional communication to coordinate their effects on feeding behavior and fertility.

\section{SF1-expressing neurons}

Like GABAergic neurons, many glutamatergic neurons co-express neuropeptides (Table 2), such as steroidogenic factor 1 (SF1) (Tong et al. 2007a). SF1 expression is restricted to, and largely comprises, the ventro-medial hypothalamus (VMH), which is known to play a key role in glucose homeostasis and appetite control (Tong et al. 2007b), as well as reproduction (Kim et al. 2010). Interestingly, brain-specific deletion of SF1 peptide expression leads to impaired fertility and late-onset obesity (Kim et al. 2010). However, these SF1-deficient mice also exhibited impaired hypothalamic development and neuronal organization, so it remains unknown whether the observed phenotype was a direct result of SF1 peptide deletion. In a more refined experiment, it was

Published by Bioscientifica Ltd 
demonstrated that SF1 neuron-specific deletion of LepR leads to obesity without causing reproductive impairments (Bingham et al. 2008). The former finding, albeit with its considerable caveats, may suggest SF1 peptide is critically involved in the regulation of fertility; yet, the latter result suggests that leptin signaling via SF1-expressing neurons is not, despite its critical role in regulating energy homeostasis. Leptin's roles in the control of metabolism and reproduction therefore appear dissociated, further highlighting the complexity of the neuroendocrine integration of metabolic and reproductive function.

\section{Tyrosine hydroxylase-expressing neurons}

Tyrosine hydroxylase (TH)-expressing neurons, which synthesize and release catecholamines (either noradrenaline or dopamine), are also modulated by leptin, insulin and ghrelin (Hommel et al. 2006, Konner et al. 2011, Zhang \& van den Pol 2016) and are involved in the regulation of energy homeostasis (Khanh et al. 2014) and fertility (Clarkson \& Herbison 2011). Several distinct TH-expressing neuronal populations have been identified and anatomically characterized; yet, the major populations thought to be involved in the regulation of energy homeostasis are the ARC and ventral tegmental area (VTA) dopaminergic populations. The TH neurons in the ARC, referred to as tuberoinfundibular dopamine (TIDA) neurons, were recently shown to play an orexigenic role in homeostatic feeding behavior (Zhang \& van den Pol 2016). Accordingly, ghrelin was shown to evoke direct excitatory effects in these neurons. A subset of these neurons were also shown to co-express GABA, which was involved in mediating some of the orexigenic effects (Zhang \& van den Pol 2016). The TH-expressing neurons in the VTA of the midbrain are thought to be involved in the regulation of hedonic (vs homeostatic) feeding behavior (Volkow et al. 2011). Accordingly, intra-VTA leptin infusion was shown to decrease dopamine neuron firing and reduce feeding (Trinko et al. 2011), whereas ghrelin infusion into the VTA stimulated dopamine release and dramatically increased food intake (Abizaid 2009). Although insulin does not appear to directly modulate dopamine release, it was shown to increase dopamine reuptake and thus, like leptin, caused an overall reduction in dopamine signaling, leading to suppressed food intake (Mebel et al. 2012). Although dopamine appears to be the major effector of these observations, sub-populations of VTA dopamine neurons have been shown to co-express GABA (Olson \& Nestler 2007) and glutamate (Alsio et al. 2011), and it thus remains a possibility that these neurotransmitters contribute to the regulation of hedonic eating. Nevertheless, these studies identify a role for both the ARC and VTA TH-expressing neurons in the regulation of feeding behavior.

With regard to fertility, dopamine has been shown to exert both acute and tonic inhibition of GNRH neuron activity (Liu \& Herbison 2013). Using electrophysiology in mouse brain slices, Liu and Herbison demonstrated that bath application of dopamine potently inhibited the firing rate of $\sim 50 \%$ of GNRH neurons, whereas application of dopamine receptor antagonists increased the basal firing of $\sim 1 / 3$ of GNRH neurons. Approximately $20 \%$ of GNRH neurons were shown to receive dopaminergic innervation from the anteroventral periventricular nucleus (Liu \& Herbison 2013); however, identifying whether the ARC or VTA dopamine population(s) are involved in the regulation of GNRH remains unclear.

In order to characterize the functional role of insulin and leptin signaling via dopamine neurons, mice exhibiting TH-specific deletion of InsR or dopamine-specific deletion of LepR were generated. Interestingly, although the TH-specific InsR KO mice exhibited an increased body weight phenotype (Konner et al. 2011), the dopaminespecific LepR KO mice showed completely normal feeding behavior and body weight, even when challenged with a high-fat diet (Liu et al. 2011). Unfortunately, their reproductive phenotypes were not assessed.

\section{NOS-expressing neurons}

Nitric oxide synthase (NOS) neurons, which produce nitric oxide, comprise a subset of hypothalamic neurons recently shown to mediate leptin's effects on the HPG axis. As mentioned previously, leptin treatment restores HPG axis function in leptin-deficient mice; yet, in the absence of nitric oxide signaling, leptin was unable to induce puberty in $o b / o b$ mice (Bellefontaine et al. 2014). This suggests nitric oxide signaling facilitates leptin's permissive effects on puberty onset and fertility. Furthermore, neuronal NOS-knockout mice are hypogonadic and infertile (Gyurko et al. 2002), and mice exhibiting NOS neuron-specific deletion of LepR exhibit delayed puberty and hyperphagic obesity (Leshan et al. 2012). However, even though NOS expression identified the population of neurons involved in mediating leptin's effects on metabolic and reproductive function, the authors suggest it is unlikely that nitric oxide signaling itself was responsible for leptin's observed metabolic effects because NOS-deficient mice show no obvious metabolic phenotype (Huang 2000). Sub-populations of

Published by Bioscientifica Ltd 
NOS neurons co-express GABA (Marshall et al. 2016) and glutamate (Lin et al. 2004), and it is therefore possible that one of these neurotransmitters is responsible for leptin's downstream metabolic effects.

\section{Other neuronal populations}

Although the aforementioned neuronal populations are arguably the key populations involved in the metabolic control of fertility, there is also evidence supporting the involvement of others. Among these, for example, are RFamide-related peptide (RFRP), melanin-concentrating hormone $(\mathrm{MCH})$ and orexin-expressing neurons. A small subpopulation of RFRP neurons, which are the mammalian orthologs to avian gonadotropin-inhibiting hormone neurons, were recently shown to co-express LepR (Poling et al. 2014), for example. However, leptin's regulation of RFRP neurons appears to occur via indirect signaling (Rizwan et al. 2014). $\mathrm{MCH}$ and orexin neurons are also implicated in the mechanism whereby low energy availability suppresses GNRH drive (Chen et al. 2007, Backholer et al. 2009, Wu et al. 2009, Skrapits et al. 2015), yet, the influence of NPY/AgRP in the suppression of reproductive function appears to be more critically involved ( $\mathrm{Wu}$ et al. 2012). Nevertheless, the influence of these 'lesser involved' populations should not be ignored as under normal physiological conditions, they still contribute to the net impact of all the inhibitory and stimulatory inputs from the GNRH neuronal network that ultimately regulate GNRH drive.

\section{Other considerations}

Intracellular signaling molecules Although emphasis is often placed on identifying the specific hormone-neuron interactions involved in the integration of metabolic and reproductive function, the role of intracellular signaling molecules should not be ignored. Leptin and insulin might act via unique receptors to exert their influence on specific neuronal populations, for example, yet a high degree of overlap and interaction between the intracellular pathways activated in response to their respective receptors being activated has been demonstrated (Niswender et al. 2001, 2003, Niswender \& Schwartz 2003, Mirshamsi et al. 2004, Benomar et al. 2005, Carvalheira et al. 2005, Morris \& Rui 2009, Berthou et al. 2011, Burgos-Ramos et al. 2011). Furthermore, critical roles for discrete signaling pathways have been established with regard to the metabolic control of fertility. For example, disruption of neural signal transducer and activator of transcription 3 (STAT3) causes obesity, diabetes and infertility in mice (Gao et al. 2004). As leptin induces STAT3 activation, one might assume the phenotype observed in these STAT3-knockout mice might be due to the inactivation of leptin-induced signaling. However, when STAT3 inactivation was restricted to LepR-expressing cells, reproductive function remained intact (Singireddy et al. 2013), highlighting that STAT3 signaling other than leptin-induced STAT3 activation may be required for reproductive function. Similarly, the mammalian target of rapamycin (mTOR), which can be activated in response to a multitude of factors, including insulin and leptin, has been identified as a central regulator of metabolic and reproductive function. Roa and coworkers demonstrated that mTOR inactivation inhibited the gonadotropic axis at puberty and also blunted the ability of leptin to promote puberty in food-restricted female rats (Roa et al. 2009, Roa \& Tena-Sempere 2014). In addition to STAT3 and mTOR signaling, phosphatidylinositol-3-kinase (PI3K) signaling is also considered a key integrator of metabolic and reproductive function. Impairments in leptin- and/or insulin-induced PI3K signaling are observed in response to chronic under- and over-nutrition, and these impairments are thought to play a role in the mechanism whereby reproductive function becomes suppressed, as reviewed by Acosta-Martinez (2011). These data, along with others, demonstrate the importance of a more complete understanding of the roles that intracellular signaling molecules play in the neuroendocrine integration of nutritional signals on fertility.

Cellular energy sensing Nutritional signals and the intracellular signaling cascades they initiate undoubtedly play an important role in the metabolic control of fertility; yet, there is also ample evidence suggesting glucose availability plays a role. As reviewed by Roland and Moenter (2011), a decrease in glucose availability mediates the effects of fasting to suppress GNRH-stimulated LH release (Bucholtz et al. 1996, Howland 1980). In vivo experiments show GNRH neurons express ATP-sensitive $\mathrm{K}^{+}\left(\mathrm{K}_{\text {ATP }}\right)$ channels and are sensitive to metabolic perturbations via these $K_{\text {ATP }}$ channels (Zhang et al. 2007). For example, blockade of $\mathrm{K}_{\mathrm{ATP}}$ channels with tolbutamide led to an increase in LH concentration regardless of energy balance (i.e. fasted or fed), yet, was unable to override the fasting-induced suppression of GNRHinduced LH secretion (Huang et al. 2008). Furthermore, there is evidence suggesting nutritional signals modulate hypothalamic glucose sensing, which in turn could

Published by Bioscientifica Ltd. 
influence GNRH neuronal function (Bruning et al. 2000, Diggs-Andrews et al. 2010). Insulin and leptin, for example, have been shown to activate $\mathrm{K}_{\mathrm{ATP}}$ channels (Spanswick et al. 2000, Mirshamsi et al. 2004).

Adenosine monophosphate (AMP)-activated protein kinase (AMPK), long considered a cell-autonomous energy sensor, can also act as an integrative metabolic sensor in the brain (Ramamurthy \& Ronnett 2006) and may therefore modulate GNRH neuronal activity, either directly or indirectly by stimulating or inhibiting neurons in the GNRH neuronal network. The activity of AMPK is normally regulated by immediate glucose availability, but is also increased in the presence of orexigenic stimuli (e.g. AgRP and ghrelin) and decreased in the presence of anorexigenic stimuli (e.g. insulin and leptin) (Minokoshi et al. 2004). This permits the possibility that whole body energy status (i.e. fuel reserves) acts in concert with immediate glucose availability to modulate the activity of neurons. Minokoshi and coworkers propose a model for how orexigenic and anorexigenic signals, through AMPK activation and suppression, respectively, result in an integrated metabolic response required for the regulation of food intake and energy balance (Minokoshi et al. 2004), and this could presumably be the case for reproductive function as well.

Astroglial cells It is also possible that astroglial cells are involved in the mechanism whereby nutritional signals modulate GNRH neuronal activity (Baroncini et al. 2007, Ojeda et al. 2008). Firstly, astrocytes play an important role in glucose metabolism (Yi et al. 2011), which, as discussed previously, is an important regulator of GNRH neuronal function. Secondly, leptin and insulin signaling via astrocytes has been demonstrated (Yi et al. 2011). Astrocytic insulin signaling modulates glucose metabolism in primary human astrocytes (Heni et al. 2011) as well as in vivo (Garcia-Caceres et al. 2016), which suggests insulin actions on astrocytes could indirectly mediate the effects of glucose availability on GNRH neuronal function. Leptin signaling in astrocytes was also recently shown to play an active role in the hypothalamic control of feeding (Kim et al. 2014). Recently, astrocytes were shown to control food intake by inhibiting AgRP neuron activity (Yang et al. 2015), which suggests astrocytes are indirectly able to promote fertility as restraining AgRP neurons would presumably facilitate GNRH drive, as mentioned previously. Furthermore, Sandau and coworkers demonstrated that the synaptic cell adhesion molecule, SynCAM1, mediates astrocyte-to-GNRH neuron adhesiveness in the mouse hypothalamus (Sandau et al. 2011b), and it was shown that astrocyte-toGNRH neuron adhesiveness via SynCAM1 is important in the control of female sexual development. For example, female mice expressing a SynCAM1 dominant negative form specifically in astrocytes exhibited delayed onset of puberty, disrupted estrus cyclicity and reduced fecundity (Sandau et al. 2011a). Astroglial cells, therefore, play a role in GNRH neuronal function and may facilitate the nutritional regulation of fertility.

Tanycytes, which are specialized bipolar glial cells located in the ARC and median eminence, also play a role in GNRH release via extension and retraction of their end-foot processes between GNRH synaptic terminals (Rodriguez et al. 2005, Baroncini et al. 2007). As reviewed by Levin and coworkers, tanycytes express tight junctions that regulate the permeability of the brain parenchyma to CSF and may therefore have the capacity to integrate a number of signals associated with energy status (Levin et al. 2004). Tanycytes express glucose transporters, as well as $\mathrm{K}_{\mathrm{ATP}}$ channels (Garcia et al. 2003), which supports the possibility that they act as glucose sensors and as a possible conduit whereby peripheral nutritional signals could modulate GNRH neuronal activity. Accordingly, tanycytes were shown to respond rapidly to changes in glucose and ATP concentration (Frayling et al. 2011).

\section{Stress responses as metabolic modulators of HPG} axis function Although the evidence supporting the linkage between metabolic impairments and reproductive disturbances is strong, others have proposed the idea of a stress-related mechanism in which reproductive function is compromised secondary to the activation of the stressresponse systems: the hypothalamic-pituitary-adrenal (HPA) and sympathoadrenal axes (Tilbrook et al. 2000, 2002). Although this review has focused on metabolic stress, it has also been shown that immune stress (i.e. inflammation), psychosocial stress, environmental stress and physical stress are associated with alterations in GNRH secretion and subsequent reproductive disturbances (O’Byrne et al. 1988, Chen et al. 1992, Li et al. 2004a,b, Berga 2006, 2008, Kinsey-Jones et al. 2009, Knox et al. 2009). It therefore stands to reason that stress itself exerts an inhibitory effect on reproductive function. However, some evidence suggests the influence of stress cannot be easily separated from its impact on nutritional signals, suggesting the final common pathway leading to compromised reproductive function may be perceived low energy availability (Loucks \& Redman 2004, Berga 2008).

Published by Bioscientifica Ltd. 
The theory behind this hypothesis is that activation of the body's stress-response systems stimulates the synthesis and secretion of glucocorticoids and catecholamines into the bloodstream (Tilbrook et al. 2000), which are counterregulatory hormones that alter fuel regulation and signal adaptive metabolic changes that are characteristic of a hypo-metabolic state (Laughlin \& Yen 1996). In other words, stress has a metabolic influence, and the stressinduced metabolic profile is similar to that of chronic low energy availability.

Conversely, however, nutritional infertility could be caused by the activation of the stress axes. For example, fasting-induced suppression of LH pulse frequency and amplitude in rats was prevented by the blockade of adrenergic signaling in the paraventricular nucleus of the hypothalamus and by blockade of HPA axis activation (Maeda et al. 1994). It therefore remains a possibility that the final pathway whereby reproductive function is suppressed might be a convergence of both metabolic and stress factors. In support of this, the combined impact of minor metabolic and psychosocial stressors (that on their own had little impact on HPG function) was shown to exert a synergistic effect on the suppression of reproductive function (Williams et al. 2007). Therefore, what remains to be determined is whether suppression of reproductive function due to metabolic stress occurs primarily via the direct signaling of hormones like leptin, insulin and ghrelin on the GNRH neuronal network or whether activation of the sympathoadrenal and HPA secretory responses is also required.

\section{Summary}

Due to the complexity and inherent redundancy of the metabolic control of fertility, impaired signaling of individual metabolic hormones through any one neuronal mediator does not appear to jeopardize neuroendocrine reproductive function (Fig. 1). This is likely due to compensation via other pathways (e.g. other nutritional signals and/or neuronal mediators) and often undermines the true physiological importance of the targeted pathway. However, widespread deletion of central leptin signaling consistently causes reproductive impairments (Mounzih et al. 1997, Quennell et al. 2009, Zuure et al. 2016), highlighting leptin is absolutely required for normal reproductive control. Furthermore, although the deletion of LepR signaling from discrete neuronal populations consistently failed to markedly impair HPG axis function, restoring LepR signaling exclusively in the PMV (Donato et al. 2011) or in AgRP neurons (O Egan and GM Anderson, unpublished observations) in LepR-null mice was sufficient to reinstate puberty and reproductive competency, respectively. This latter finding, along with the demonstration that AgRP ablation (Wu et al. 2012) and AgRP deficiency (Sheffer-Babila et al. 2013) in $o b / o b$ mice also restore fertility, highlights that unrestrained

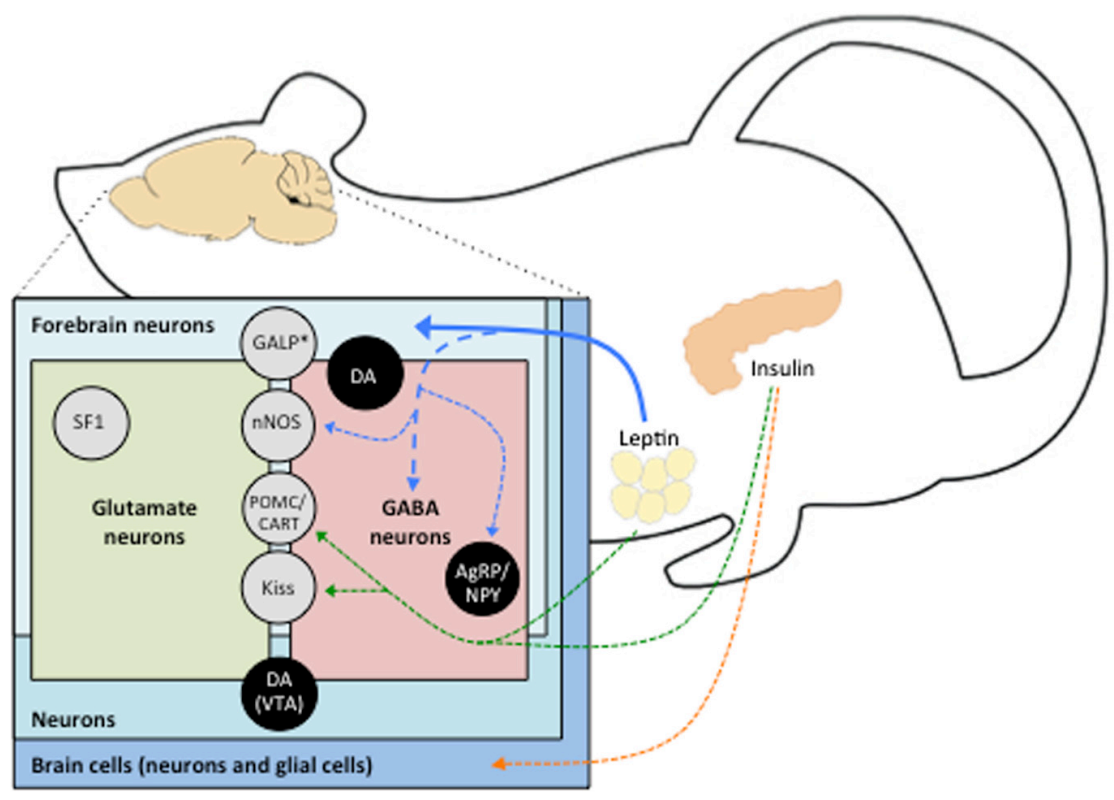

Figure 1

Schematic diagram illustrating the major neuronal populations targeted by nutritional signals to promote (grey circles) or suppress (black circles) the neuroendocrine reproductive axis. Solid arrows represent pathways identified to be absolutely required for fertility, whereas dotted arrows represent pathways shown to be critically involved but not required (as identified through Cre-LoxP gene deletion experiments). The thickness of arrow represents an estimate of the potency of the effect based on the reviewed literature. Blue arrows indicate leptin effects, orange arrows indicate insulin effects and green arrows indicate combined leptin and insulin effects. Pathways not represented by arrows are not critically involved (e.g. effects of ghrelin are not shown as the deletion of ghrelin or its receptor do not disrupt reproductive drive). AgRP/NPY, agouti-related peptide/neuropeptide $Y$; DA, dopamine; GALP, galanin-like peptide; Kiss, kisspeptin; nNOS, neuronal nitric oxide synthase; POMC/CART, pro-opiomelanocortin/cocaine- and amphetamine-regulated transcript; SF1, steroidogenic factor-1; VTA, ventral tegmental area. *, co-expression data is not available. 
AgRP expression is critically involved in the suppression of HPG function due to nutritional stress.

In contrast, widespread deletion of central insulin signaling (Bruning et al. 2000, Evans et al. 2014b, 2015) or ghrelin signaling (Sun et al. 2008) does not cause infertility, demonstrating they are not required to permit sufficient HPG activation. This is not to say they are not important modulators of GNRH drive, but rather highlights sufficient compensation can occur in their absence to preserve reproductive function. However, pathological insulin signaling via GNRH neurons due to diet-induced obesity promotes infertility (DiVall et al. 2015), demonstrating insulin can directly influence HPG axis function. Furthermore, it remains a possibility that insulin critically regulates reproductive function through its combined actions on the hypothalamus and pituitary (Brothers et al. 2010).

In conclusion, the neuroendocrine integration of metabolic and reproductive function is complex, and many nutritional signals play a role in conveying information regarding peripheral energy status centrally to the GNRH neuronal network. Due to the inherent redundancies in the metabolic control of fertility, the use of transgenic models to test the functional role of individual metabolically relevant signaling pathways has largely been unsuccessful. Nevertheless, these investigations have importantly demonstrated how adaptable and robust the neuroendocrine reproductive axis is in regard to its ability to integrate and respond to multiple metabolic cues.

\section{Declaration of interest}

The authors declare that there is no conflict of interest that could be perceived as prejudicing the impartiality of this review.

\section{Funding}

M C E was supported by The Health Sciences Career Development Program Postdoctoral Fellowship from the University of Otago, and research was supported by the Health Research Council of New Zealand.

\section{Author contribution statement}

M C E drafted the manuscript and G M A provided support and edited the final manuscript.

\section{References}

Abe M, Saito M, Ikeda H \& Shimazu T 1991 Increased neuropeptide Y content in the arcuato-paraventricular hypothalamic neuronal system in both insulin-dependent and non-insulin-dependent diabetic rats. Brain Research 539 223-227. (doi:10.1016/00068993(91)91624-A)

Abizaid A 2009 Ghrelin and dopamine: new insights on the peripheral regulation of appetite. Journal of Neuroendocrinology 21 787-793. (doi:10.1111/j.1365-2826.2009.01896.x)

Acosta-Martinez M 2011 PI3K: an attractive candidate for the central integration of metabolism and reproduction. Frontiers in Endocrinology 2 110. (doi:10.3389/fendo.2011.00110)

Adler BA \& Crowley WR 1986 Evidence for gamma-aminobutyric acid modulation of ovarian hormonal effects on luteinizing hormone secretion and hypothalamic catecholamine activity in the female rat. Endocrinology 118 91-97. (doi:10.1210/endo-118-1-91)

Ahima RS, Prabakaran D, Mantzoros C, Qu D, Lowell B, Maratos-Flier E \& Flier JS 1996 Role of leptin in the neuroendocrine response to fasting. Nature 382 250-252. (doi:10.1038/382250a0)

Alsio J, Nordenankar K, Arvidsson E, Birgner C, Mahmoudi S, Halbout B, Smith C, Fortin GM, Olson L, Descarries L, et al. 2011 Enhanced sucrose and cocaine self-administration and cue-induced drug seeking after loss of VGLUT2 in midbrain dopamine neurons in mice. Journal of Neuroscience 31 12593-12603. (doi:10.1523/ JNEUROSCI.2397-11.2011)

Asakawa A, Inui A, Kaga T, Yuzuriha H, Nagata T, Ueno N, Makino S, Fujimiya M, Niijima A, Fujino MA, et al. 2001 Ghrelin is an appetitestimulatory signal from stomach with structural resemblance to motilin. Gastroenterology 120 337-345. (doi:10.1053/gast.2001.22158)

Backholer K, Smith J \& Clarke IJ 2009 Melanocortins may stimulate reproduction by activating orexin neurons in the dorsomedial hypothalamus and kisspeptin neurons in the preoptic area of the ewe. Endocrinology 150 5488-5497. (doi:10.1210/en.2009-0604)

Balthasar N, Coppari R, McMinn J, Liu SM, Lee CE, Tang V, Kenny CD, McGovern RA, Chua SC Jr, Elmquist JK, et al. 2004 Leptin receptor signaling in POMC neurons is required for normal body weight homeostasis. Neuron 42 983-991. (doi:10.1016/j.neuron.2004.06.004)

Barash IA, Cheung CC, Weigle DS, Ren H, Kabigting EB, Kuijper JL, Clifton DK \& Steiner RA 1996 Leptin is a metabolic signal to the reproductive system. Endocrinology 137 3144-3147. (doi:10.1210/ en.137.7.3144)

Baroncini M, Allet C, Leroy D, Beauvillain JC, Francke JP \& Prevot V 2007 Morphological evidence for direct interaction between gonadotrophin-releasing hormone neurones and astroglial cells in the human hypothalamus. Journal of Neuroendocrinology 19 691-702. (doi:10.1111/j.1365-2826.2007.01576.x)

Baskin DG, Figlewicz Lattemann D, Seeley RJ, Woods SC, Porte D Jr \& Schwartz MW 1999 Insulin and leptin: dual adiposity signals to the brain for the regulation of food intake and body weight. Brain Research 848 114-123. (doi:10.1016/S0006-8993(99)01974-5)

Bates SH, Stearns WH, Dundon TA, Schubert M, Tso AW, Wang Y, Banks AS, Lavery HJ, Haq AK, Maratos-Flier E, et al. 2003 STAT3 signalling is required for leptin regulation of energy balance but not reproduction. Nature 421 856-859. (doi:10.1038/nature01388)

Beak SA, Heath MM, Small CJ, Morgan DG, Ghatei MA, Taylor AD, Buckingham JC, Bloom SR \& Smith DM 1998 Glucagon-like peptide-1 stimulates luteinizing hormone-releasing hormone secretion in a rodent hypothalamic neuronal cell line. Journal of Clinical Investigation 101 1334-1341. (doi:10.1172/JCI610)

Belgardt BF \& Bruning JC 2010 CNS leptin and insulin action in the control of energy homeostasis. Annals of the New York Academy of Sciences 1212 97-113. (doi:10.1111/j.1749-6632.2010.05799.x)

Bell-Horner CL, Dohi A, Nguyen Q, Dillon GH \& Singh M 2006 ERK/ MAPK pathway regulates GABAA receptors. Journal of Neurobiology 66 1467-1474. (doi:10.1002/neu.20327)

Bellefontaine N, Chachlaki K, Parkash J, Vanacker C, Colledge W, de Tassigny XD, Garthwaite J, Bouret SG \& Prevot V 2014 Leptindependent neuronal NO signaling in the preoptic hypothalamus facilitates reproduction. Journal of Clinical Investigation 124 2550-2559. (doi:10.1172/JCI65928)

Published by Bioscientifica Ltd. http://jme.endocrinology-journals.org

DOI: 10.1530/JME-16-0212
() 2017 Society for Endocrinology Printed in Great Britain 
Benoit SC, Air EL, Coolen LM, Strauss R, Jackman A, Clegg DJ, Seeley RJ \& Woods SC 2002 The catabolic action of insulin in the brain is mediated by melanocortins. Journal of Neuroscience 22 9048-9052.

Benomar Y, Wetzler S, Larue-Achagiotis C, Djiane J, Tome D \& Taouis M 2005 In vivo leptin infusion impairs insulin and leptin signalling in liver and hypothalamus. Molecular and Cellular Endocrinology 242 59-66. (doi:10.1016/j.mce.2005.07.003)

Berga S 2006 Stress, metabolism and reproductive compromise. Human Reproduction 21 I32-I32. (doi:10.1093/oxfordjournals.humrep. a002529)

Berga SL 2008 Stress and reproduction: a tale of false dichotomy? Endocrinology 149 867-868. (doi:10.1210/en.2008-0004)

Berga SL, Mortola JF, Girton L, Suh B, Laughlin G, Pham P \& Yen SS 1989 Neuroendocrine aberrations in women with functional hypothalamic amenorrhea. Journal of Clinical Endocrinology and Metabolism 68 301-308. (doi:10.1210/jcem-68-2-301)

Berthou F, Rouch C, Gertler A, Gerozissis K \& Taouis M 2011 Chronic central leptin infusion differently modulates brain and liver insulin signaling. Molecular and Cellular Endocrinology 337 89-95. (doi:10.1016/j.mce.2011.02.005)

Bingham NC, Anderson KK, Reuter AL, Stallings NR \& Parker KL 2008 Selective loss of leptin receptors in the ventromedial hypothalamic nucleus results in increased adiposity and a metabolic syndrome. Endocrinology 149 2138-2148. (doi:10.1210/en.2007-1200)

Boden G, Chen X, Mozzoli M \& Ryan I 1996 Effect of fasting on serum leptin in normal human subjects. Journal of Clinical Endocrinology and Metabolism 81 3419-3423. (doi:10.1210/jc.81.9.3419)

Brady LS, Smith MA, Gold PW \& Herkenham M 1990 Altered expression of hypothalamic neuropeptide mRNAs in food-restricted and fooddeprived rats. Neuroendocrinology 52 441-447.

(doi:10.1159/000125626)

Brann DW \& Mahesh VB 1995 Glutamate: a major neuroendocrine excitatory signal mediating steroid effects on gonadotropin secretion. Journal of Steroid Biochemistry and Molecular Biology $\mathbf{5 3}$ 325-329. (doi:10.1016/0960-0760(95)00070-G)

Brothers KJ, Wu S, DiVall SA, Messmer MR, Kahn CR, Miller RS, Radovick S, Wondisford FE \& Wolfe A 2010 Rescue of obesityinduced infertility in female mice due to a pituitary-specific knockout of the insulin receptor. Cell Metabolism 12 295-305. (doi:10.1016/j.cmet.2010.06.010)

Bruning JC, Gautam D, Burks DJ, Gillette J, Schubert M, Orban PC, Klein R, Krone W, Muller-Wieland D \& Kahn CR 2000 Role of brain insulin receptor in control of body weight and reproduction. Science 289 2122-2125. (doi:10.1126/science.289.5487.2122)

Bucholtz DC, Vidwans NM, Herbosa CG, Schillo KK \& Foster DL 1996 Metabolic interfaces between growth and reproduction. V. Pulsatile luteinizing hormone secretion is dependent on glucose availability. Endocrinology 137 601-607. (doi:10.1210/en.137.2.601)

Burgos-Ramos E, Chowen JA, Arilla-Ferreiro E, Canelles S, Argente J \& Barrios V 2011 Chronic central leptin infusion modifies the response to acute central insulin injection by reducing the interaction of the insulin receptor with IRS2 and increasing its association with SOCS3. Journal of Neurochemistry 117 175-185. (doi:10.1111/j.1471-4159.2011.07191.x)

Cameron JL \& Nosbisch C 1991 Suppression of pulsatile luteinizinghormone and testosterone secretion during short-term food restriction in the adult male rhesus-monkey (macaca-mulatta). Endocrinology 128 1532-1540. (doi:10.1210/endo-128-3-1532)

Carro E, Pinilla L, Seoane LM, Considine RV, Aguilar E, Casanueva FF \& Dieguez C 1997 Influence of endogenous leptin tone on the estrous cycle and luteinizing hormone pulsatility in female rats. Neuroendocrinology 66 375-377. (doi:10.1159/000127262)

Carvalheira JB, Torsoni MA, Ueno M, Amaral ME, Araujo EP, Velloso LA, Gontijo JA \& Saad MJ 2005 Cross-talk between the insulin and leptin signaling systems in rat hypothalamus. Obesity Research $\mathbf{1 3}$ 48-57. (doi:10.1038/oby.2005.7)
Castellano JM, Navarro VM, Fernandez-Fernandez R, Nogueiras R, Tovar S, Roa J, Vazquez MJ, Vigo E, Casanueva FF, Aguilar E, et al. 2005 Changes in hypothalamic KiSS-1 system and restoration of pubertal activation of the reproductive axis by kisspeptin in undernutrition. Endocrinology 146 3917-3925. (doi:10.1210/en.2005-0337)

Castellano JM, Navarro VM, Fernandez-Fernandez R, Roa J, Vigo E, Pineda R, Dieguez C, Aguilar E, Pinilla L \& Tena-Sempere M 2006 Expression of hypothalamic KiSS-1 system and rescue of defective gonadotropic responses by kisspeptin in streptozotocin-induced diabetic male rats. Diabetes 55 2602-2610. (doi:10.2337/db051584)

Castellano JM, Bentsen AH, Mikkelsen JD \& Tena-Sempere M 2010 Kisspeptins: bridging energy homeostasis and reproduction. Brain Research 1364 129-138. (doi:10.1016/j.brainres.2010.08.057)

Chan JL, Heist K, DePaoli AM, Veldhuis JD \& Mantzoros CS 2003 The role of falling leptin levels in the neuroendocrine and metabolic adaptation to short-term starvation in healthy men. Journal of Clinical Investigation 111 1409-1421. (doi:10.1172/JCI200317490)

Chehab FF, Mounzih K, Lu R \& Lim ME 1997 Early onset of reproductive function in normal female mice treated with leptin. Science 275 88-90. (doi:10.1126/science.275.5296.88)

Chen MD, O’Byrne KT, Chiappini SE, Hotchkiss J \& Knobil E 1992 Hypoglycemic 'stress' and gonadotropin-releasing hormone pulse generator activity in the rhesus monkey: role of the ovary. Neuroendocrinology 56 666-673. (doi:10.1159/000126291)

Chen LL, Jiang QY, Zhu XT, Shu G, Bin YF, Wang XQ, Gao P \& Zhang YL 2007 Ghrelin ligand-receptor mRNA expression in hypothalamus, proventriculus and liver of chicken (Gallus gallus domesticus): studies on ontogeny and feeding condition. Comparative Biochemistry and Physiology: Part A Molecular and Integrative Physiology 147 893-902. (doi:10.1016/j.cbpa.2007.02.017)

Cheong RY, Czieselsky K, Porteous R \& Herbison AE 2015 Expression of ESR1 in glutamatergic and GABAergic neurons is essential for normal puberty onset, estrogen feedback, and fertility in female mice. Journal of Neuroscience 35 14533-14543. (doi:10.1523/ JNEUROSCI.1776-15.2015)

Christian CA \& Moenter SM 2010 The neurobiology of preovulatory and estradiol-induced gonadotropin-releasing hormone surges. Endocrine Reviews 31 544-577. (doi:10.1210/er.2009-0023)

Clarkson J \& Herbison AE 2011 Dual phenotype kisspeptin-dopamine neurones of the rostral periventricular area of the third ventricle project to gonadotrophin-releasing hormone neurones. Journal of Neuroendocrinology 23 293-301. (doi:10.1111/j.1365-2826.2011.02107.x)

Codner E, Merino PM \& Tena-Sempere M 2012 Female reproduction and type 1 diabetes: from mechanisms to clinical findings. Human Reproduction Update 18 568-585. (doi:10.1093/humupd/dms024)

Comninos AN, Jayasena CN \& Dhillo WS 2014 The relationship between gut and adipose hormones, and reproduction. Human Reproduction Update 20 153-174. (doi:10.1093/humupd/dmt033)

Compagnucci C, Compagnucci GE, Lomniczi A, Mohn C, Vacas I, Cebral E, Elverdin JC, Friedman S, Rettori V \& Boyer PM 2002 Effect of nutritional stress on the hypothalamo-pituitary-gonadal axis in the growing male rat. Neuroimmunomodulation 10 153-162. (doi:10.1159/000067177)

Cone RD 2005 Anatomy and regulation of the central melanocortin system. Nature Neuroscience 8 571-578. (doi:10.1038/nn1455)

Corr M, De Souza MJ, Toombs RJ \& Williams NI 2011 Circulating leptin concentrations do not distinguish menstrual status in exercising women. Human Reproduction 26 685-694. (doi:10.1093/humrep/ deq375)

Cowley MA, Pronchuk N, Fan W, Dinulescu DM, Colmers WF \& Cone RD 1999 Integration of NPY, AGRP, and melanocortin signals in the hypothalamic paraventricular nucleus: evidence of a cellular basis for the adipostat. Neuron 24 155-163. (doi:10.1016/S08966273(00)80829-6)

Published by Bioscientifica Ltd. 
Cowley MA, Smart JL, Rubinstein M, Cerdan MG, Diano S, Horvath TL, Cone RD \& Low MJ 2001 Leptin activates anorexigenic POMC neurons through a neural network in the arcuate nucleus. Nature 411 480-484. (doi:10.1038/35078085)

Cowley MA, Smith RG, Diano S, Tschop M, Pronchuk N, Grove KL, Strasburger CJ, Bidlingmaier M, Esterman M, Heiman ML, et al. 2003 The distribution and mechanism of action of ghrelin in the CNS demonstrates a novel hypothalamic circuit regulating energy homeostasis. Neuron 37 649-661. (doi:10.1016/S08966273(03)00063-1)

Cravo RM, Frazao R, Perello M, Osborne-Lawrence S, Williams KW, Zigman JM, Vianna C \& Elias CF 2013 Leptin signaling in kiss1 neurons arises after pubertal development. PLOS ONE 8 e58698. (doi:10.1371/journal.pone.0058698)

Crown A, Clifton DK \& Steiner RA 2007 Neuropeptide signaling in the integration of metabolism and reproduction. Neuroendocrinology $\mathbf{8 6}$ 175-182. (doi:10.1159/000109095)

Cunningham MJ 2004 Galanin-like peptide as a link between metabolism and reproduction. Journal of Neuroendocrinology $\mathbf{1 6}$ 717-723. (doi:10.1111/j.1365-2826.2004.01221.x)

Cunningham MJ, Scarlett JM \& Steiner RA 2002 Cloning and distribution of galanin-like peptide mRNA in the hypothalamus and pituitary of the macaque. Endocrinology 143 755-763. (doi:10.1210/ endo.143.3.8661)

De Bond JP, Tolson KP, Nasamran C, Kauffman AS \& Smith JT 2016 Unaltered hypothalamic metabolic gene expression in Kiss1r KO mice despite obesity and reduced energy expenditure. Journal of Neuroendocrinology 28 jne.12430. (doi:10.1111/jne.12430)

De Souza MJ, Leidy HJ, O’Donnell E, Lasley B \& Williams NI 2004 Fasting ghrelin levels in physically active women: relationship with menstrual disturbances and metabolic hormones. Journal of Clinical Endocrinology and Metabolism 89 3536-3542. (doi:10.1210/jc.2003032007)

De Souza MJ, Lee DK, VanHeest JL, Scheid JL, West SL \& Williams NI 2007 Severity of energy-related menstrual disturbances increases in proportion to indices of energy conservation in exercising women. Fertility and Sterility 88 971-975. (doi:10.1016/j. fertnstert.2006.11.171)

Diggs-Andrews KA, Zhang X, Song Z, Daphna-Iken D, Routh VH \& Fisher SJ 2010 Brain insulin action regulates hypothalamic glucose sensing and the counterregulatory response to hypoglycemia. Diabetes 59 2271-2280. (doi:10.2337/db10-0401)

Divall SA, Williams TR, Carver SE, Koch L, Bruning JC, Kahn CR, Wondisford F, Radovick S \& Wolfe A 2010 Divergent roles of growth factors in the GnRH regulation of puberty in mice. Journal of Clinical Investigation 120 2900-2909. (doi:10.1172/JCI41069)

DiVall SA, Herrera D, Sklar B, Wu S, Wondisford F, Radovick S \& Wolfe A 2015 Insulin receptor signaling in the GnRH neuron plays a role in the abnormal GnRH pulsatility of obese female mice. PLOS ONE $\mathbf{1 0}$ e0119995. (doi:10.1371/journal.pone.0119995)

Donato J Jr, Cravo RM, Frazao R, Gautron L, Scott MM, Lachey J, Castro IA, Margatho LO, Lee S, Lee C, et al. 2011 Leptin's effect on puberty in mice is relayed by the ventral premamillary nucleus and does not require signaling in Kiss1 neurons. Journal of Clinical Investigation 121 355-368. (doi:10.1172/JCI45106)

Donoso AO, Seltzer AM, Navarro CE, Cabrera RJ, Lopez FJ \& NegroVilar A 1994 Regulation of luteinizing hormone-releasing hormone and luteinizing hormone secretion by hypothalamic amino acids. Brazilian Journal of Medical and Biological Research 27 921-932.

Dupont C, Cordier AG, Junien C, Mandon-Pepin B, Levy R \& ChavattePalmer P 2012 Maternal environment and the reproductive function of the offspring. Theriogenology $\mathbf{7 8} 1405-1414$. (doi:10.1016/j. theriogenology.2012.06.016)

Elias CF, Aschkenasi C, Lee C, Kelly J, Ahima RS, Bjorbaek C, Flier JS, Saper CB \& Elmquist JK 1999 Leptin differentially regulates NPY and
POMC neurons projecting to the lateral hypothalamic area. Neuron 23 775-786. (doi:10.1016/S0896-6273(01)80035-0)

Evans MC, Rizwan M, Mayer C, Boehm U \& Anderson GM $2014 a$ Evidence that insulin signalling in gonadotrophin-releasing hormone and kisspeptin neurones does not play an essential role in metabolic regulation of fertility in mice. Journal of Neuroendocrinology 26 468-479. (doi:10.1111/jne.12166)

Evans MC, Rizwan MZ \& Anderson GM 2014b Insulin action on GABA neurons is a critical regulator of energy balance but not fertility in mice. Endocrinology 155 4368-4379. (doi:10.1210/en.2014-1412)

Evans MC, Rizwan MZ \& Anderson GM 2015 Insulin does not target CamkIIalpha neurones to critically regulate the neuroendocrine reproductive axis in mice. Journal of Neuroendocrinology 27 899-910. (doi:10.1111/jne.12330)

Farkas I, Vastagh C, Sarvari M \& Liposits Z 2013 Ghrelin decreases firing activity of gonadotropin-releasing hormone $(\mathrm{GnRH})$ neurons in an estrous cycle and endocannabinoid signaling dependent manner. PLOS ONE 8 e78178. (doi:10.1371/journal.pone.0078178)

Farooqi IS, Jebb SA, Langmack G, Lawrence E, Cheetham CH, Prentice AM, Hughes IA, McCamish MA \& O'Rahilly S 1999 Effects of recombinant leptin therapy in a child with congenital leptin deficiency. New England Journal of Medicine 341 879-884. (doi:10.1056/NEJM199909163411204)

Farooqi IS, Matarese G, Lord GM, Keogh JM, Lawrence E, Agwu C, Sanna V, Jebb SA, Perna F, Fontana S, et al. 2002 Beneficial effects of leptin on obesity, T cell hyporesponsiveness, and neuroendocrine/ metabolic dysfunction of human congenital leptin deficiency. Journal of Clinical Investigation 110 1093-1103. (doi:10.1172/JCI0215693)

Forbes S, Li XF, Kinsey-Jones J \& O'Byrne K 2009 Effects of ghrelin on Kisspeptin mRNA expression in the hypothalamic medial preoptic area and pulsatile luteinising hormone secretion in the female rat. Neuroscience Letters 460 143-147. (doi:10.1016/j.neulet.2009.05.060)

Fraley GS, Scarlett JM, Shimada I, Teklemichael DN, Acohido BV, Clifton DK \& Steiner RA 2004 Effects of diabetes and insulin on the expression of galanin-like peptide in the hypothalamus of the rat. Diabetes 53 1237-1242. (doi:10.2337/diabetes.53.5.1237)

Frayling C, Britton R \& Dale N 2011 ATP-mediated glucosensing by hypothalamic tanycytes. Journal of Physiology 589 2275-2286. (doi:10.1113/jphysiol.2010.202051)

Fu LY \& van den Pol AN 2010 Kisspeptin directly excites anorexigenic proopiomelanocortin neurons but inhibits orexigenic neuropeptide Y cells by an indirect synaptic mechanism. Journal of Neuroscience $\mathbf{3 0}$ 10205-10219. (doi:10.1523/JNEUROSCI.2098-10.2010)

Furuta M, Funabashi T \& Kimura F 2001 Intracerebroventricular administration of ghrelin rapidly suppresses pulsatile luteinizing hormone secretion in ovariectomized rats. Biochemical and Biophysical Research Communications 288 780-785. (doi:10.1006/ bbrc.2001.5854)

Gao Q, Wolfgang MJ, Neschen S, Morino K, Horvath TL, Shulman GI \& Fu XY 2004 Disruption of neural signal transducer and activator of transcription 3 causes obesity, diabetes, infertility, and thermal dysregulation. PNAS 101 4661-4666. (doi:10.1073/pnas.0303992101)

Garcia MA, Millan C, Balmaceda-Aguilera C, Castro T, Pastor P, Montecinos H, Reinicke K, Zuniga F, Vera JC, Onate SA, et al. 2003 Hypothalamic ependymal-glial cells express the glucose transporter GLUT2, a protein involved in glucose sensing. Journal of Neurochemistry 86 709-724. (doi:10.1046/j.1471-4159.2003.01892.x)

Garcia-Galiano D, van Ingen Schenau D, Leon S, Krajnc-Franken MA, Manfredi-Lozano M, Romero-Ruiz A, Navarro VM, Gaytan F, van Noort PI, Pinilla L, et al. 2012 Kisspeptin signaling is indispensable for neurokinin B, but not glutamate, stimulation of gonadotropin secretion in mice. Endocrinology 153 316-328. (doi:10.1210/en.20111260)

Garcia-Caceres C, Quarta C, Varela L, Gao Y, Gruber T, Legutko B, Jastroch M, Johansson P, Ninkovic J, Yi CX, et al. 2016 Astrocytic http://jme.endocrinology-journals.org

DOI: 10.1530/JME-16-0212
() 2017 Society for Endocrinology Printed in Great Britain
Published by Bioscientifica Ltd 
insulin signaling couples brain glucose uptake with nutrient availability. Cell 166 867-880. (doi:10.1016/j.cell.2016.07.028)

Guan JL, Okuda H, Takenoya F, Kintaka Y, Yagi M, Wang L, Seki M, Hori Y, Kageyama H \& Shioda S 2008 Synaptic relationships between proopiomelanocortin- and ghrelin-containing neurons in the rat arcuate nucleus. Regulatory Peptides 145 128-132. (doi:10.1016/j. regpep.2007.09.028)

Gyurko R, Leupen S \& Huang PL 2002 Deletion of exon 6 of the neuronal nitric oxide synthase gene in mice results in hypogonadism and infertility. Endocrinology 143 2767-2774. (doi:10.1210/endo.143.7.8921)

Han SK, Gottsch ML, Lee KJ, Popa SM, Smith JT, Jakawich SK, Clifton DK, Steiner RA \& Herbison AE 2005 Activation of gonadotropin-releasing hormone neurons by kisspeptin as a neuroendocrine switch for the onset of puberty. Journal of Neuroscience 25 11349-11356. (doi:10.1523/JNEUROSCI.3328-05.2005)

Havel PJ, Hahn TM, Sindelar DK, Baskin DG, Dallman MF, Weigle DS \& Schwartz MW 2000 Effects of streptozotocin-induced diabetes and insulin treatment on the hypothalamic melanocortin system and muscle uncoupling protein 3 expression in rats. Diabetes $\mathbf{4 9}$ 244-252. (doi:10.2337/diabetes.49.2.244)

Heni M, Hennige AM, Peter A, Siegel-Axel D, Ordelheide AM, Krebs N, Machicao F, Fritsche A, Haring HU \& Staiger H 2011 Insulin promotes glycogen storage and cell proliferation in primary human astrocytes. PLOS ONE 6 e21594. (doi:10.1371/journal.pone.0021594)

Herbison AE 2016 Control of puberty onset and fertility by gonadotropin-releasing hormone neurons. Nature Reviews Endocrinology 12 452-466. (doi:10.1038/nrendo.2016.70)

Herbison AE \& Moenter SM 2011 Depolarising and hyperpolarising actions of GABA(A) receptor activation on gonadotrophin-releasing hormone neurones: towards an emerging consensus. Journal of Neuroendocrinology 23 557-569.

(doi:10.1111/j.1365-2826.2011.02145.x)

Hill JW \& Levine JE 2003 Abnormal response of the neuropeptide Y-deficient mouse reproductive axis to food deprivation but not lactation. Endocrinology 144 1780-1786. (doi:10.1210/en.2002221024)

Hill JW, Elias CF, Fukuda M, Williams KW, Berglund ED, Holland WL, Cho YR, Chuang JC, Xu Y, Choi M, et al. 2010 Direct insulin and leptin action on pro-opiomelanocortin neurons is required for normal glucose homeostasis and fertility. Cell Metabolism 11 286-297. (doi:10.1016/j.cmet.2010.03.002)

Holst B \& Schwartz TW 2004 Constitutive ghrelin receptor activity as a signaling set-point in appetite regulation. Trends in Pharmacological Sciences 25 113-117. (doi:10.1016/j.tips.2004.01.010)

Holst B, Cygankiewicz A, Jensen TH, Ankersen M \& Schwartz TW 2003 High constitutive signaling of the ghrelin receptor-identification of a potent inverse agonist. Molecular Endocrinology 17 2201-2210. (doi:10.1210/me.2003-0069)

Hommel JD, Trinko R, Sears RM, Georgescu D, Liu ZW, Gao XB, Thurmon JJ, Marinelli M \& DiLeone RJ 2006 Leptin receptor signaling in midbrain dopamine neurons regulates feeding. Neuron 51 801-810. (doi:10.1016/j.neuron.2006.08.023)

Howland BE 1980 Effect of glucoprivation induced by 2-deoxy-d-glucose on serum gonadotropin levels, pituitary response to GnRH and progesterone-induced release of luteinizing hormone in rats. Hormone and Metabolic Research 12 520-523. (doi:10.1055/s-2007-999190)

Huang PL 2000 Mouse models of nitric oxide synthase deficiency. Journal of the American Society of Nephrology 11 S120-S123.

Huang W, Acosta-Martinez M, Horton TH \& Levine JE 2008 Fastinginduced suppression of LH secretion does not require activation of ATP-sensitive potassium channels. American Journal of Physiology: Endocrinology and Metabolism 295 E1439-E1446. (doi:10.1152/ ajpendo.90615.2008)
Hummel KP, Dickie MM \& Coleman DL 1966 Diabetes, a new mutation in the mouse. Science 153 1127-1128. (doi:10.1126/ science.153.3740.1127)

Huo L, Gamber K, Greeley S, Silva J, Huntoon N, Leng XH \& Bjorbaek C 2009 Leptin-dependent control of glucose balance and locomotor activity by POMC neurons. Cell Metabolism 9 537-547.

Ingalls AM, Dickie MM \& Snell GD 1950 Obese, a new mutation in the house mouse. Journal of Heredity 41 317-318.

Iremonger KJ, Constantin S, Liu X \& Herbison AE 2010 Glutamate regulation of GnRH neuron excitability. Brain Research 1364 35-43. (doi:10.1016/j.brainres.2010.08.071)

Irwig MS, Fraley GS, Smith JT, Acohido BV, Popa SM, Cunningham MJ, Gottsch ML, Clifton DK \& Steiner RA 2004 Kisspeptin activation of gonadotropin releasing hormone neurons and regulation of KiSS-1 mRNA in the male rat. Neuroendocrinology 80 264-272. (doi:10.1159/000083140)

Jayasena CN, Nijher GM, Chaudhri OB, Murphy KG, Ranger A, Lim A, Patel D, Mehta A, Todd C, Ramachandran R, et al. 2009 Subcutaneous injection of kisspeptin-54 acutely stimulates gonadotropin secretion in women with hypothalamic amenorrhea, but chronic administration causes tachyphylaxis. Journal of Clinical Endocrinology and Metabolism 94 4315-4323. (doi:10.1210/jc.20090406)

Jayasena CN, Nijher GM, Abbara A, Murphy KG, Lim A, Patel D, Mehta A, Todd C, Donaldson M, Trew GH, et al. 2010 Twice-weekly administration of kisspeptin-54 for 8 weeks stimulates release of reproductive hormones in women with hypothalamic amenorrhea. Clinical Pharmacology and Therapeutics 88 840-847. (doi:10.1038/ clpt.2010.204)

Jureus A, Cunningham MJ, McClain ME, Clifton DK \& Steiner RA 2000 Galanin-like peptide (GALP) is a target for regulation by leptin in the hypothalamus of the rat. Endocrinology 141 2703-2706. (doi:10.1210/en.141.7.2703)

Kalamatianos T, Grimshaw SE, Poorun R, Hahn JD \& Coen CW 2008 Fasting reduces KiSS- 1 expression in the anteroventral periventricular nucleus (AVPV): effects of fasting on the expression of KiSS-1 and neuropeptide $\mathrm{Y}$ in the AVPV or arcuate nucleus of female rats. Journal of Neuroendocrinology 20 1089-1097. (doi:10.1111/j.1365-2826.2008.01757.x)

Kalra SP, Ueno N \& Kalra PS 2005 Stimulation of appetite by ghrelin is regulated by leptin restraint: peripheral and central sites of action. Journal of Nutrition 135 1331-1335.

Katsiki N \& Hatzitolios AI 2010 Insulin-sensitizing agents in the treatment of polycystic ovary syndrome: an update. Current Opinion in Obstetrics and Gynecology 22 466-476. (doi:10.1097/ GCO.0b013e32833e1264)

Kauffman AS, Buenzle J, Fraley GS \& Rissman EF 2005 Effects of galaninlike peptide (GALP) on locomotion, reproduction, and body weight in female and male mice. Hormones and Behavior 48 141-151. (doi:10.1016/j.yhbeh.2005.01.010)

Kawano M, Kawasaki A, Sakata-Haga H, Fukui Y, Kawano H, Nogami H \& Hisano S 2006 Particular subpopulations of midbrain and hypothalamic dopamine neurons express vesicular glutamate transporter 2 in the rat brain. Journal of Comparative Neurology 498 581-592. (doi:10.1002/cne.21054)

Khanh DV, Choi YH, Moh SH, Kinyua AW \& Kim KW 2014 Leptin and insulin signaling in dopaminergic neurons: relationship between energy balance and reward system. Frontiers in Psychology 5846. (doi:10.3389/fpsyg.2014.00846)

Kim KW, Li S, Zhao H, Peng B, Tobet SA, Elmquist JK, Parker KL \& Zhao L 2010 CNS-specific ablation of steroidogenic factor 1 results in impaired female reproductive function. Molecular Endocrinology $\mathbf{2 4}$ 1240-1250. (doi:10.1210/me.2009-0206)

Kim JG, Suyama S, Koch M, Jin S, Argente-Arizon P, Argente J, Liu ZW, Zimmer MR, Jeong JK, Szigeti-Buck K, et al. 2014 Leptin signaling in http://jme.endocrinology-journals.org

DOI: $10.1530 / J M E-16-0212$
() 2017 Society for Endocrinology Printed in Great Britain
Published by Bioscientifica Ltd 
astrocytes regulates hypothalamic neuronal circuits and feeding. Nature Neuroscience 17 908-910. (doi:10.1038/nn.3725)

Kinsey-Jones JS, Li XF, Knox AM, Wilkinson ES, Zhu XL, Chaudhary AA Milligan SR, Lightman SL \& O'Byrne KT 2009 Down-regulation of hypothalamic kisspeptin and its receptor, Kiss1r, mRNA expression is associated with stress-induced suppression of luteinising hormone secretion in the female rat. Journal of Neuroendocrinology 21 20-29. (doi:10.1111/j.1365-2826.2008.01807.x)

Klenke U, Taylor-Burds C \& Wray S 2014 Metabolic influences on reproduction: adiponectin attenuates GnRH neuronal activity in female mice. Endocrinology 155 1851-1863. (doi:10.1210/en.2013-1677)

Kluge M 2012 Ghrelin suppresses secretion of gonadotropins in women Reproductive Sciences 19 Np3-Np3. (doi:10.1177/1933719112459242)

Kluge M, Schussler P, Uhr M, Yassouridis A \& Steiger A 2007 Ghrelin suppresses secretion of luteinizing hormone in humans. Journal of Clinical Endocrinology and Metabolism 92 3202-3205. (doi:10.1210/ jc.2007-0593)

Kluge M, Uhr M, Bleninger P, Yassouridis A \& Steiger A 2009 Ghrelin suppresses secretion of FSH in males. Clinical Endocrinology $\mathbf{7 0}$ 920-923. (doi:10.1111/j.1365-2265.2008.03440.x)

Kluge M, Schussler P, Schmidt D, Uhr M \& Steiger A 2012 Ghrelin suppresses secretion of luteinizing hormone (LH) and folliclestimulating hormone (FSH) in women. Journal of Clinical Endocrinology and Metabolism 97 E448-E451. (doi:10.1210/jc.2011-2607)

Kluge M, Schmidt D, Uhr M \& Steiger A 2013 Ghrelin suppresses nocturnal secretion of luteinizing hormone (LH) and thyroid stimulating hormone (TSH) in patients with major depression. Journal of Psychiatric Research 47 1236-1239. (doi:10.1016/j. jpsychires.2013.05.010)

Knox AM, Li XF, Kinsey-Jones JS, Wilkinson ES, Wu XQ, Cheng YS, Milligan SR, Lightman SL \& O’Byrne KT 2009 Neonatal lipopolysaccharide exposure delays puberty and alters hypothalamic Kiss1 and Kiss1r mRNA expression in the female rat. Journal of Neuroendocrinology 21 683-689. (doi:10.1111/j.13652826.2009.01885.x)

Kocsis K, Kiss J, Csaki A \& Halasz B 2003 Location of putative glutamatergic neurons projecting to the medial preoptic area of the rat hypothalamus. Brain Research Bulletin 61 459-468. (doi:10.1016/ S0361-9230(03)00180-1)

Konner AC, Janoschek R, Plum L, Jordan SD, Rother E, Ma X, Xu C, Enriori P, Hampel B, Barsh GS, et al. 2007 Insulin action in AgRP-expressing neurons is required for suppression of hepatic glucose production. Cell Metabolism 5 438-449. (doi:10.1016/j.cmet.2007.05.004)

Konner AC, Hess S, Tovar S, Mesaros A, Sanchez-Lasheras C, Evers N, Verhagen LA, Bronneke HS, Kleinridders A, Hampel B, et al. 2011 Role for insulin signaling in catecholaminergic neurons in control of energy homeostasis. Cell Metabolism 13 720-728. (doi:10.1016/j. cmet.2011.03.021)

Korner J, Savontaus E, Chua SC Jr, Leibel RL \& Wardlaw SL 2001 Leptin regulation of Agrp and Npy mRNA in the rat hypothalamus. Journal of Neuroendocrinology 13 959-966. (doi:10.1046/j.1365-2826.2001.00716.x)

Kuramochi M, Kohno D, Onaka T, Kato S \& Yada T 2005 Galanin-like peptide and ghrelin increase cytosolic $\mathrm{Ca} 2+$ in neurons containing growth hormone-releasing hormone in the arcuate nucleus. Regulatory Peptides 126 85-89. (doi:10.1016/j.regpep.2004.08.017)

Kuramochi M, Onaka T, Kohno D, Kato S \& Yada T 2006 Galanin-like peptide stimulates food intake via activation of neuropeptide $\mathrm{Y}$ neurons in the hypothalamic dorsomedial nucleus of the rat. Endocrinology 147 1744-1752. (doi:10.1210/en.2005-0907)

Laughlin GA \& Yen SS 1996 Nutritional and endocrine-metabolic aberrations in amenorrheic athletes. Journal of Clinical Endocrinology and Metabolism 81 4301-4309. (doi:10.1210/jc.81.12.4301)

Laughlin GA \& Yen SS 1997 Hypoleptinemia in women athletes: absence of a diurnal rhythm with amenorrhea. Journal of Clinical
Endocrinology and Metabolism 82 318-321. (doi:10.1210/ jcem.82.1.3840)

Laughlin GA, Morales AJ \& Yen SS 1997 Serum leptin levels in women with polycystic ovary syndrome: the role of insulin resistance/ hyperinsulinemia. Journal of Clinical Endocrinology and Metabolism $\mathbf{8 2}$ 1692-1696. (doi:10.1210/jc.82.6.1692)

Laughlin GA, Dominguez CE \& Yen SS 1998 Nutritional and endocrinemetabolic aberrations in women with functional hypothalamic amenorrhea. Journal of Clinical Endocrinology and Metabolism $\mathbf{8 3}$ 25-32. (doi:10.1210/jc.83.1.25)

Lebrethon MC, Aganina A, Fournier M, Gerard A, Parent AS \& Bourguignon JP 2007 Effects of in vivo and in vitro administration of ghrelin, leptin and neuropeptide mediators on pulsatile gonadotrophin-releasing hormone secretion from male rat hypothalamus before and after puberty. Journal of Neuroendocrinology 19 181-188. (doi:10.1111/j.1365-2826.2006.01518.x)

Leranth C, MacLusky NJ, Shanabrough M \& Naftolin F 1988 Immunohistochemical evidence for synaptic connections between pro-opiomelanocortin-immunoreactive axons and LH-RH neurons in the preoptic area of the rat. Brain Research 449 167-176. (doi:10.1016/0006-8993(88)91035-9)

Leshan RL, Greenwald-Yarnell M, Patterson CM, Gonzalez IE \& Myers MG 2012 Leptin action through hypothalamic nitric oxide synthase-1-expressing neurons controls energy balance. Nature Medicine 18 820-U236. (doi:10.1038/nm.2724)

Levin BE, Routh VH, Kang L, Sanders NM \& Dunn-Meynell AA 2004 Neuronal glucosensing: what do we know after 50 years? Diabetes $\mathbf{5 3}$ 2521-2528. (doi:10.2337/diabetes.53.10.2521)

Li XF, Bowe JE, Mitchell JC, Brain SD, Lightman SL \& O'Byrne KT 2004a Stress-induced suppression of the gonadotropin-releasing hormone pulse generator in the female rat: a novel neural action for calcitonin gene-related peptide. Endocrinology 145 1556-1563. (doi:10.1210/en.2003-1609)

Li XF, Edward J, Mitchell JC, Shao B, Bowes JE, Coen CW, Lightman SL \& O’Byrne KT 2004b Differential effects of repeated restraint stress on pulsatile lutenizing hormone secretion in female Fischer, Lewis and Wistar rats. Journal of Neuroendocrinology 16 620-627. (doi:10.1111/j.1365-2826.2004.01209.x)

Lin LH, Edwards RH, Fremeau RT, Fujiyama F, Kaneko T \& Talman WT 2004 Localization of vesicular glutamate transporters and neuronal nitric oxide synthase in rat nucleus tractus solitarii. Neuroscience $\mathbf{1 2 3}$ 247-255. (doi:10.1016/j.neuroscience.2003.08.063)

Liu X \& Herbison AE 2013 Dopamine regulation of gonadotropinreleasing hormone neuron excitability in male and female mice. Endocrinology 154 340-350. (doi:10.1210/en.2012-1602)

Liu J, Perez SM, Zhang W, Lodge DJ \& Lu XY 2011 Selective deletion of the leptin receptor in dopamine neurons produces anxiogenic-like behavior and increases dopaminergic activity in amygdala. Molecular Psychiatry 16 1024-1038. (doi:10.1038/mp.2011.36)

Lopez FJ, Donoso AO \& Negro-Vilar A 1990 Endogenous excitatory amino acid neurotransmission regulates the estradiol-induced LH surge in ovariectomized rats. Endocrinology 126 1771-1773. (doi:10.1210/endo-126-3-1771)

Loucks AB \& Thuma JR 2003 Luteinizing hormone pulsatility is disrupted at a threshold of energy availability in regularly menstruating women. Journal of Clinical Endocrinology and Metabolism 88 297-311. (doi:10.1210/jc.2002-020369)

Loucks AB \& Redman LM 2004 The effect of stress on menstrual function. Trends in Endocrinology and Metabolism 15 466-471. (doi:10.1016/j.tem.2004.10.005)

Loucks AB, Verdun M \& Heath EM 1998 Low energy availability, not stress of exercise, alters LH pulsatility in exercising women. Journal of Applied Physiology 84 37-46.

Louis GW, Greenwald-Yarnell M, Phillips R, Coolen LM, Lehman MN \& Myers MG Jr 2011 Molecular mapping of the neural pathways http://jme.endocrinology-journals.org

DOI: 10.1530/JME-16-0212
() 2017 Society for Endocrinology Printed in Great Britain
Published by Bioscientifica Ltd 
linking leptin to the neuroendocrine reproductive axis. Endocrinology 152 2302-2310. (doi:10.1210/en.2011-0096)

MacLusky NJ, Cook S, Scrocchi L, Shin J, Kim J, Vaccarino F, Asa SL \& Drucker DJ 2000 Neuroendocrine function and response to stress in mice with complete disruption of glucagon-like peptide-1 receptor signaling. Endocrinology 141 752-762. (doi:10.1210/ en.141.2.752)

Maeda KI, Cagampang FRA, Coen CW \& Tsukamura H 1994 Involvement of the catecholaminergic input to the paraventricular nucleus and of corticotropin-releasing hormone in the fastinginduced suppression of luteinizing-hormone release in female rats. Endocrinology 134 1718-1722. (doi:10.1210/en.134.4.1718)

Manfredi-Lozano M, Roa J, Ruiz-Pino F, Piet R, Garcia-Galiano D, Pineda R, Zamora A, Leon S, Sanchez-Garrido MA, RomeroRuiz A, et al. 2016 Defining a novel leptin-melanocortin-kisspeptin pathway involved in the metabolic control of puberty. Molecular Metabolism 5 844-857. (doi:10.1016/j.molmet.2016.08.003)

Marshall CJ, Desroziers E, McLennan T \& Campbell RE 2016 Defining subpopulations of arcuate nucleus GABA neurons in male, female and prenatally androgenized female mice. Neuroendocrinology. [in press]. (doi:10.1159/000452105)

McShane TM, May T, Miner JL \& Keisler DH 1992 Central actions of neuropeptide-Y may provide a neuromodulatory link between nutrition and reproduction. Biology of Reproduction 46 1151-1157. (doi:10.1095/biolreprod46.6.1151)

Mebel DM, Wong JC, Dong YJ \& Borgland SL 2012 Insulin in the ventral tegmental area reduces hedonic feeding and suppresses dopamine concentration via increased reuptake. European Journal of Neuroscience 36 2336-2346. (doi:10.1111/j.1460-9568.2012.08168.x)

Meister B 2007 Neurotransmitters in key neurons of the hypothalamus that regulate feeding behavior and body weight. Physiology and Behavior 92 263-271. (doi:10.1016/j.physbeh.2007.05.021)

Merrill CB, Friend LN, Newton ST, Hopkins ZH \& Edwards JG 2015 Ventral tegmental area dopamine and GABA neurons: Physiological properties and expression of mRNA for endocannabinoid biosynthetic elements. Scientific Reports 5 16176. (doi:10.1038/ srep16176)

Minokoshi Y, Alquier T, Furukawa N, Kim YB, Lee A, Xue B, Mu J, Foufelle F, Ferre P, Birnbaum MJ, et al. 2004 AMP-kinase regulates food intake by responding to hormonal and nutrient signals in the hypothalamus. Nature 428 569-574. (doi:10.1038/nature02440)

Mirshamsi S, Laidlaw HA, Ning K, Anderson E, Burgess LA, Gray A, Sutherland C \& Ashford ML 2004 Leptin and insulin stimulation of signalling pathways in arcuate nucleus neurones: PI3K dependent actin reorganization and KATP channel activation. BMC Neuroscience 5 54. (doi:10.1186/1471-2202-5-54)

Mitsushima D, Hei DL \& Terasawa E 1994 gamma-Aminobutyric acid is an inhibitory neurotransmitter restricting the release of luteinizing hormone-releasing hormone before the onset of puberty. PNAS 91 395-399. (doi:10.1073/pnas.91.1.395)

Mohr MA, Leathley E \& Fraley GS 2012 Hypothalamic galanin-like peptide (GALP) rescues the onset of puberty in food-restricted weanling rats. Journal of Neuroendocrinology 24 1412-1422. (doi:10.1111/j.1365-2826.2012.02351.x)

Morris DL \& Rui LY 2009 Recent advances in understanding leptin signaling and leptin resistance. American Journal of Physiology: Endocrinology and Metabolism 297 E1247-E1259. (doi:10.1152/ ajpendo.00274.2009)

Mounzih K, Lu R \& Chehab FF 1997 Leptin treatment rescues the sterility of genetically obese ob/ob males. Endocrinology 138 1190-1193. (doi:10.1210/en.138.3.1190)

Nandi A, Wang X, Accili D \& Wolgemuth DJ 2010 The effect of insulin signaling on female reproductive function independent of adiposity and hyperglycemia. Endocrinology 151 1863-1871. (doi:10.1210/ en.2009-0788)
Nikolarakis KE, Loeffler JP, Almeida OF \& Herz A 1988 Pre- and postsynaptic actions of GABA on the release of hypothalamic gonadotropin-releasing hormone (GnRH). Brain Research Bulletin 21 677-683. (doi:10.1016/0361-9230(88)90208-0)

Niswender KD \& Schwartz MW 2003 Insulin and leptin revisited: adiposity signals with overlapping physiological and intracellular signaling capabilities. Frontiers in Neuroendocrinology 24 1-10. (doi:10.1016/S0091-3022(02)00105-X)

Niswender KD, Morton GJ, Stearns WH, Rhodes CJ, Myers MG Jr \& Schwartz MW 2001 Intracellular signalling. Key enzyme in leptininduced anorexia. Nature 413 794-795. (doi:10.1038/35101657)

Niswender KD, Gallis B, Blevins JE, Corson MA, Schwartz MW \& Baskin DG 2003 Immunocytochemical detection of phosphatidylinositol 3-kinase activation by insulin and leptin. Journal of Histochemistry and Cytochemistry 51 275-283. (doi:10.1177/002215540305100302)

O'Byrne KT, Lunn SF \& Dixson AF 1988 Effects of acute stress on the patterns of LH secretion in the common marmoset (Callithrix jacchus). Journal of Endocrinology 118 259-264. (doi:10.1677/ joe.0.1180259)

Ojeda SR, Lomniczi A \& Sandau US 2008 Glial-gonadotrophin hormone $(\mathrm{GnRH})$ neurone interactions in the median eminence and the control of GnRH secretion. Journal of Neuroendocrinology 20 732-742. (doi:10.1111/j.1365-2826.2008.01712.x)

Ollmann MM, Wilson BD, Yang YK, Kerns JA, Chen Y, Gantz I \& Barsh GS 1997 Antagonism of central melanocortin receptors in vitro and in vivo by agouti-related protein. Science 278 135-138. (doi:10.1126/science.278.5335.135)

Olson VG \& Nestler EJ 2007 Topographical organization of GABAergic neurons within the ventral tegmental area of the rat. Synapse $\mathbf{6 1}$ 87-95. (doi:10.1002/syn.20345)

Ovesjo ML, Gamstedt M, Collin M \& Meister B 2001 GABAergic nature of hypothalamic leptin target neurones in the ventromedial arcuate nucleus. Journal of Neuroendocrinology 13 505-516. (doi:10.1046/j.1365-2826.2001.00662.x)

Ping L, Mahesh VB, Bhat GK \& Brann DW 1997 Regulation of gonadotropin-releasing hormone and luteinizing hormone secretion by AMPA receptors. Evidence for a physiological role of AMPA receptors in the steroid-induced luteinizing hormone surge. Neuroendocrinology 66 246-253. (doi:10.1159/000127245)

Pinilla L, Fernandez-Fernandez R, Vigo E, Navarro VM, Roa J, Castellano JM, Pineda R, Tena-Sempere M \& Aguilar E 2006 Stimulatory effect of PYY-(3-36) on gonadotropin secretion is potentiated in fasted rats. American Journal of Physiology: Endocrinology and Metabolism 290 E1162-E1171. (doi:10.1152/ajpendo.00469.2005)

Pinilla L, Fernandez-Fernandez R, Roa J, Castellano JM, Tena-Sempere M \& Aguilar E 2007 Selective role of neuropeptide Y receptor subtype Y2 in the control of gonadotropin secretion in the rat. American Journal of Physiology: Endocrinology and Metabolism 293 E1385-E1392. (doi:10.1152/ajpendo.00274.2007)

Poling MC, Shieh MP, Munaganuru N, Luo E \& Kauffman AS 2014 Examination of the influence of leptin and acute metabolic challenge on RFRP-3 neurons of mice in development and adulthood. Neuroendocrinology 100 317-333. (doi:10.1159/000369276)

Qi Y, Inoue K, Fu M, Inui A \& Herzog H 2015 Chronic overproduction of ghrelin in the hypothalamus leads to temporal increase in food intake and body weight. Neuropeptides $5023-28$. (doi:10.1016/j. npep.2015.02.002)

Qiu X, Dao H, Wang M, Heston A, Garcia KM, Sangal A, Dowling AR, Faulkner LD, Molitor SC, Elias CF, et al. 2015 Insulin and leptin signaling interact in the mouse kiss1 neuron during the peripubertal period. PLOS ONE 10 e121974. (doi:10.1371/journal.pone.0121974)

Quennell JH, Mulligan AC, Tups A, Liu X, Phipps SJ, Kemp CJ, Herbison AE, Grattan DR \& Anderson GM 2009 Leptin indirectly regulates gonadotropin-releasing hormone neuronal function. Endocrinology 150 2805-2812. (doi:10.1210/en.2008-1693) http://jme.endocrinology-journals.org

DOI: 10.1530/JME-16-0212
๑ 2017 Society for Endocrinology Printed in Great Britain
Published by Bioscientifica Ltd 
Quennell JH, Howell CS, Roa J, Augustine RA, Grattan DR \& Anderson GM 2011 Leptin deficiency and diet-induced obesity reduce hypothalamic kisspeptin expression in mice. Endocrinology 152 1541-1550. (doi:10.1210/en.2010-1100)

Ramamurthy S \& Ronnett GV 2006 Developing a head for energy sensing: AMP-activated protein kinase as a multifunctional metabolic sensor in the brain. Journal of Physiology 574 85-93. (doi:10.1113/ jphysiol.2006.110122)

Rizwan MZ, Harbid AA, Inglis MA, Quennell JH \& Anderson GM 2014 Evidence that hypothalamic RFamide related peptide-3 neurones are not leptin-responsive in mice and rats. Journal of Neuroendocrinology 26 247-257. (doi:10.1111/jne.12140)

Roa J \& Herbison AE 2012 Direct regulation of GnRH neuron excitability by arcuate nucleus POMC and NPY neuron neuropeptides in female mice. Endocrinology 153 5587-5599. (doi:10.1210/en.2012-1470)

Roa J \& Tena-Sempere M 2014 Connecting metabolism and reproduction: roles of central energy sensors and key molecular mediators. Molecular and Cellular Endocrinology 397 4-14. (doi:10.1016/j.mce.2014.09.027)

Roa J, Garcia-Galiano D, Varela L, Sanchez-Garrido MA, Pineda R, Castellano JM, Ruiz-Pino F, Romero M, Aguilar E, Lopez M, et al. 2009 The mammalian target of rapamycin as novel central regulator of puberty onset via modulation of hypothalamic Kiss1 system. Endocrinology 150 5016-5026. (doi:10.1210/en.2009-0096)

Rodriguez EM, Blazquez JL, Pastor FE, Pelaez B, Pena P, Peruzzo B \& Amat P 2005 Hypothalamic tanycytes: a key component of brainendocrine interaction. International Review of Cytology 247 89-164. (doi:10.1016/S0074-7696(05)47003-5)

Roland AV \& Moenter SM 2011 Regulation of gonadotropin-releasing hormone neurons by glucose. Trends in Endocrinology and Metabolism 22 443-449. (doi:10.1016/j.tem.2011.07.001)

Sandau US, Mungenast AE, Alderman Z, Sardi SP, Fogel AI, Taylor B, Parent AS, Biederer T, Corfas G \& Ojeda SR 2011a SynCAM1, a synaptic adhesion molecule, is expressed in astrocytes and contributes to erbB4 receptor-mediated control of female sexual development. Endocrinology 152 2364-2376. (doi:10.1210/en.2010-1435)

Sandau US, Mungenast AE, McCarthy J, Biederer T, Corfas G \& Ojeda SR $2011 b$ The synaptic cell adhesion molecule, SynCAM1, mediates astrocyte-to-astrocyte and astrocyte-to-GnRH neuron adhesiveness in the mouse hypothalamus. Endocrinology 152 2353-2363. (doi:10.1210/en.2010-1434)

Sanz E, Quintana A, Deem JD, Steiner RA, Palmiter RD \& McKnight GS 2015 Fertility-regulating Kiss1 neurons arise from hypothalamic POMC-expressing progenitors. Journal of Neuroscience 35 5549-5556. (doi:10.1523/JNEUROSCI.3614-14.2015)

Sato I, Arima H, Ozaki N, Watanabe M, Goto M, Hayashi M, Banno R, Nagasaki H \& Oiso Y 2005 Insulin inhibits neuropeptide Y gene expression in the arcuate nucleus through GABAergic systems. Journal of Neuroscience 25 8657-8664. (doi:10.1523/ JNEUROSCI.2739-05.2005)

Schaeffer M, Langlet F, Lafont C, Molino F, Hodson DJ, Roux T, Lamarque L, Verdie P, Bourrier E, Dehouck B, et al. 2013 Rapid sensing of circulating ghrelin by hypothalamic appetite-modifying neurons. PNAS 110 1512-1517. (doi:10.1073/pnas.1212137110)

Scheid JL \& De Souza MJ 2010 Menstrual irregularities and energy deficiency in physically active women: the role of ghrelin, PYY and adipocytokines. Medicine and Sport Science 55 82-102. (doi:10.1159/000321974)

Schneider LF \& Warren MP 2006 Functional hypothalamic amenorrhea is associated with elevated ghrelin and disordered eating. Fertility and Sterility 86 1744-1749. (doi:10.1016/j.fertnstert.2006.05.051)

Schneider LF, Monaco SE \& Warren MP 2008 Elevated ghrelin level in women of normal weight with amenorrhea is related to disordered eating. Fertility and Sterility 90 121-128. (doi:10.1016/j. fertnstert.2007.06.002)
Schwartz MW, Marks JL, Sipols AJ, Baskin DG, Woods SC, Kahn SE \& Porte D Jr 1991 Central insulin administration reduces neuropeptide $\mathrm{Y}$ mRNA expression in the arcuate nucleus of food-deprived lean $(\mathrm{Fa} /$ Fa) but not obese (fa/fa) Zucker rats. Endocrinology 128 2645-2647. (doi:10.1210/endo-128-5-2645)

Sheffer-Babila S, Sun Y, Israel DD, Liu SM, Neal-Perry G \& Chua SC Jr 2013 Agouti-related peptide plays a critical role in leptin's effects on female puberty and reproduction. American Journal of Physiology: Endocrinology and Metabolism 305 E1512-E1520. (doi:10.1152/ ajpendo.00241.2013)

Shi H, Sorrell JE, Clegg DJ, Woods SC \& Seeley RJ 2010 The roles of leptin receptors on POMC neurons in the regulation of sex-specific energy homeostasis. Physiology \& Behavior 100 165-172. (doi:10.1016/j.physbeh.2010.02.018)

Shioda S, Kageyama H, Takenoya F \& Shiba K 2011 Galanin-like peptide: a key player in the homeostatic regulation of feeding and energy metabolism? International Journal of Obesity 35 619-628. (doi:10.1038/ijo.2010.202)

Singireddy AV, Inglis MA, Zuure WA, Kim JS \& Anderson GM 2013 Neither signal transducer and activator of transcription 3 (STAT3) or STAT5 signaling pathways are required for leptin's effects on fertility in mice. Endocrinology 154 2434-2445. (doi:10.1210/en.2013-1109)

Skrapits K, Kanti V, Savanyu Z, Maurnyi C, Szenci O, Horvath A, Borsay BA, Herczeg L, Liposits Z \& Hrabovszky E 2015 Lateral hypothalamic orexin and melanin-concentrating hormone neurons provide direct input to gonadotropin-releasing hormone neurons in the human. Frontiers in Cellular Neuroscience 9 348. (doi:10.3389/fncel.2015.00348)

Smith JT 2009 Sex steroid control of hypothalamic Kiss1 expression in sheep and rodents: comparative aspects. Peptides 30 94-102. (doi:10.1016/j.peptides.2008.08.013)

Smith JT, Acohido BV, Clifton DK \& Steiner RA 2006 KiSS-1 neurones are direct targets for leptin in the ob/ob mouse. Journal of Neuroendocrinology 18 298-303. (doi:10.1111/j.1365-2826.2006.01417.x)

Souter I, Baltagi LM, Kuleta D, Meeker JD \& Petrozza JC 2011 Women, weight, and fertility: the effect of body mass index on the outcome of superovulation/intrauterine insemination cycles. Fertility and Sterility 95 1042-1047. (doi:10.1016/j.fertnstert.2010.11.062)

Spanswick D, Smith MA, Mirshamsi S, Routh VH \& Ashford ML 2000 Insulin activates ATP-sensitive K+ channels in hypothalamic neurons of lean, but not obese rats. Nature Neuroscience 3 757-758. (doi:10.1038/77660)

Stoyanovitch AG, Johnson MA, Clifton DK, Steiner RA \& Fraley GS 2005 Galanin-like peptide rescues reproductive function in the diabetic rat. Diabetes 54 2471-2476. (doi:10.2337/diabetes.54.8.2471)

Sullivan SD \& Moenter SM 2004 Gamma-aminobutyric acid neurons integrate and rapidly transmit permissive and inhibitory metabolic cues to gonadotropin-releasing hormone neurons. Endocrinology 145 1194-1202. (doi:10.1210/en.2003-1374)

Sullivan SD, DeFazio RA \& Moenter SM 2003 Metabolic regulation of fertility through presynaptic and postsynaptic signaling to gonadotropin-releasing hormone neurons. Journal of Neuroscience $\mathbf{2 3}$ 8578-8585.

Sun YX, Ahmed S \& Smith RG 2003 Deletion of ghrelin impairs neither growth nor appetite. Molecular and Cellular Biology 23 7973-7981. (doi:10.1128/MCB.23.22.7973-7981.2003)

Sun YX, Butte NF, Garcia JM \& Smith RG 2008 Characterization of adult ghrelin and ghrelin receptor knockout mice under positive and negative energy balance. Endocrinology 149 843-850. (doi:10.1210/ en.2007-0271)

Takatsu Y, Matsumoto H, Ohtaki T, Kumano S, Kitada C, Onda H, Nishimura O \& Fujino M 2001 Distribution of galanin-like peptide in the rat brain. Endocrinology 142 1626-1634. (doi:10.1210/ endo.142.4.8089)

Takenoya F, Guan JL, Kato M, Sakuma Y, Kintaka Y, Kitamura Y, Kitamura S, Okuda H, Takeuchi M, Kageyama H, et al. 2006 Neural

Published by Bioscientifica Ltd 
interaction between galanin-like peptide (GALP)- and luteinizing hormone-releasing hormone (LHRH)-containing neurons. Peptides $\mathbf{2 7}$ 2885-2893. (doi:10.1016/j.peptides.2006.05.012)

Tena-Sempere M 2006 KiSS-1 and reproduction: focus on its role in the metabolic regulation of fertility. Neuroendocrinology 83 275-281. (doi:10.1159/000095549)

Tilbrook AJ, Turner AI \& Clarke IJ 2000 Effects of stress on reproduction in non-rodent mammals: the role of glucocorticoids and sex differences. Reviews of Reproduction 5 105-113. (doi:10.1530/ ror.0.0050105)

Tilbrook AJ, Turner AI \& Clarke IJ 2002 Stress and reproduction: central mechanisms and sex differences in non-rodent species. Stress $\mathbf{5}$ 83-100. (doi:10.1080/10253890290027912)

Tong Q, Ye C, McCrimmon RJ, Dhillon H, Choi B, Kramer MD, Yu J, Yang Z, Christiansen LM, Lee CE, et al. 2007a Synaptic glutamate release by ventromedial hypothalamic neurons is part of the neurocircuitry that prevents hypoglycemia. Cell Metabolism $\mathbf{5}$ 383-393. (doi:10.1016/j.cmet.2007.04.001)

Tong QC, Ye CP, McCrimmon RJ, Dhillon H, Choi B, Kramer MD, Yu J, Yang ZF, Christiansen LM, Lee CE, et al. 2007b Synaptic glutamate release by ventromedial hypothalamic neurons is part of the neurocircuitry that prevents hypoglycemia. Cell Metabolism 5 383-393. (doi:10.1016/j.cmet.2007.04.001)

Trinko R, Gan GL, Gao XB, Sears RM, Guarnieri DJ \& DiLeone RJ 2011 Erk1/2 mediates leptin receptor signaling in the ventral tegmental area. PLOS ONE 6 e27180. (doi:10.1371/journal.pone.0027180)

True C, Verma S, Grove KL \& Smith MS 2013 Cocaine- and amphetamine-regulated transcript is a potent stimulator of GnRH and kisspeptin cells and may contribute to negative energy balanceinduced reproductive inhibition in females. Endocrinology 154 2821-2832. (doi:10.1210/en.2013-1156)

van de Wall E, Leshan R, Xu AW, Balthasar N, Coppari R, Liu SM, Jo YH, MacKenzie RG, Allison DB, Dun NJ, et al. 2008 Collective and individual functions of leptin receptor modulated neurons controlling metabolism and ingestion. Endocrinology 149 1773-1785.

Volkow ND, Wang GJ \& Baler RD 2011 Reward, dopamine and the control of food intake: implications for obesity. Trends in Cognitive Sciences 15 37-46. (doi:10.1016/j.tics.2010.11.001)

Vulliemoz NR, Xiao E, Xia-Zhang L, Wardlaw SL \& Ferin M 2005 Central infusion of agouti-related peptide suppresses pulsatile luteinizing hormone release in the ovariectomized rhesus monkey. Endocrinology 146 784-789. (doi:10.1210/en.2004-1093)

Wade GN \& Jones JE 2004 Neuroendocrinology of nutritional infertility. American Journal of Physiology: Regulatory, Integrative and Comparative Physiology 287 R1277-R1296. (doi:10.1152/ajpregu.00475.2004)

Wan Q, Xiong ZG, Man HY, Ackerley CA, Braunton J, Lu WY, Becker LE, MacDonald JF \& Wang YT 1997 Recruitment of functional GABA(A) receptors to postsynaptic domains by insulin. Nature 388 686-690. (doi:10.1038/41792)

Wang J \& Leibowitz KL 1997 Central insulin inhibits hypothalamic galanin and neuropeptide $\mathrm{Y}$ gene expression and peptide release in intact rats. Brain Research 777 231-236. (doi:10.1016/S00068993(97)00963-3)

Wattez JS, Delahaye F, Lukaszewski MA, Risold PY, Eberle D, Vieau D \& Breton C 2013 Perinatal nutrition programs the hypothalamic melanocortin system in offspring. Hormone and Metabolic Research 45 980-990. (doi:10.1055/s-0033-1357182)

Welt CK, Chan JL, Bullen J, Murphy R, Smith P, DePaoli AM, Karalis A \& Mantzoros CS 2004 Recombinant human leptin in women with hypothalamic amenorrhea. New England Journal of Medicine $\mathbf{3 5 1}$ 987-997. (doi:10.1056/NEJMoa040388)

Williams NI, Berga SL \& Cameron JL 2007 Synergism between psychosocial and metabolic stressors: impact on reproductive function in cynomolgus monkeys. American Journal of Physiology: Endocrinology and Metabolism 293 E270-E276. (doi:10.1152/ajpendo.00108.2007)

Williams KW, Margatho LO, Lee CE, Choi M, Lee S, Scott MM, Elias CF \& Elmquist JK 2010 Segregation of acute leptin and insulin effects in distinct populations of arcuate proopiomelanocortin neurons. Journal of Neuroscience 30 2472-2479. (doi:10.1523/

JNEUROSCI.3118-09.2010)

Wittmann G, Hrabovszky E \& Lechan RM 2013 Distinct glutamatergic and GABAergic subsets of hypothalamic pro-opiomelanocortin neurons revealed by in situ hybridization in male rats and mice. Journal of Comparative Neurology 521 3287-3302.

Wu M, Dumalska I, Morozova E, van den Pol A \& Alreja M 2009 Melanin-concentrating hormone directly inhibits GnRH neurons and blocks kisspeptin activation, linking energy balance to reproduction. PNAS 106 17217-17222. (doi:10.1073/pnas.0908200106)

Wu Q, Whiddon BB \& Palmiter RD 2012 Ablation of neurons expressing agouti-related protein, but not melanin concentrating hormone, in leptin-deficient mice restores metabolic functions and fertility. PNAS 109 3155-3160. (doi:10.1073/pnas.1120501109)

Yang L, Qi Y \& Yang Y 2015 Astrocytes control food intake by inhibiting AGRP neuron activity via adenosine A1 receptors. Cell Reports $\mathbf{1 1}$ 798-807. (doi:10.1016/j.celrep.2015.04.002)

Yi CX, Habegger KM, Chowen JA, Stern J \& Tschop MH 2011 A role for astrocytes in the central control of metabolism. Neuroendocrinology 93 143-149. (doi:10.1159/000324888)

Zhang X \& van den Pol AN 2016 Hypothalamic arcuate nucleus tyrosine hydroxylase neurons play orexigenic role in energy homeostasis. Nature Neuroscience 19 1341-1347. (doi:10.1038/nn.4372)

Zhang Y, Proenca R, Maffei M, Barone M, Leopold L \& Friedman JM 1994 Positional cloning of the mouse obese gene and its human homologue. Nature 372 425-432.

Zhang C, Bosch MA, Levine JE, Ronnekleiv OK \& Kelly MJ 2007 Gonadotropin-releasing hormone neurons express K(ATP) channels that are regulated by estrogen and responsive to glucose and metabolic inhibition. Journal of Neuroscience 27 10153-10164. (doi:10.1523/JNEUROSCI.1657-07.2007)

Zhu CC, Zhang H, Zhang JS, Li Z, Zhao J, Li W \& Zhang YQ 2013 Inhibition of ghrelin signaling improves the reproductive phenotype of male ob/ob mouse. Fertility and Sterility 99 918-926. (doi:10.1016/j.fertnstert.2012.11.022)

Zuure WA, Roberts AL, Quennell JH \& Anderson GM 2013 Leptin signaling in GABA neurons, but not glutamate neurons, is required for reproductive function. Journal of Neuroscience 33 17874-17883. (doi:10.1523/JNEUROSCI.2278-13.2013)

Zuure WA, Quennell JH \& Anderson GM 2016 Leptin responsive and GABAergic projections to the rostral preoptic area in mice. Journal of Neuroendocrinology 28 12357. (doi:10.1111/jne.12357)

Received in final form 23 December 2016

Accepted 5 January 2017

Accepted Preprint published online 5 January 2017 http://jme.endocrinology-journals.org

DOI: 10.1530/JME-16-0212
() 2017 Society for Endocrinology Printed in Great Britain
Published by Bioscientifica Ltd 